\title{
Ehrengard, Kierkegaard, and the Secret Note
}

Bunch, Mads

Published in:

Scandinavian Studies (Provo)

Publication date:

2013

Document version

Early version, also known as pre-print

Citation for published version (APA):

Bunch, M. (2013). Ehrengard, Kierkegaard, and the Secret Note. Scandinavian Studies (Provo), 85(4), 489-523. 


\section{SCANDINAVIAN STUDIES}

Winter 20I3 Volume 85 Number 4

John Weinstock Assimilation of the Sámi Ellen Rees The Place of Nation in Camilla Collett's Amtmandens Døttre Magnus Fjalldal Heimskringla as Propaganda Emily Irwin Strindberg Meets Jewish Theology Mads Bunch "Ehrengard," Kierkegaard, and the Secret Note 


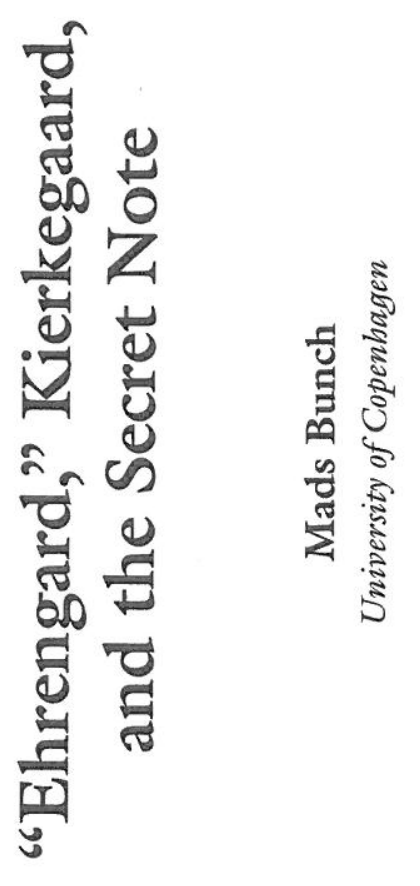

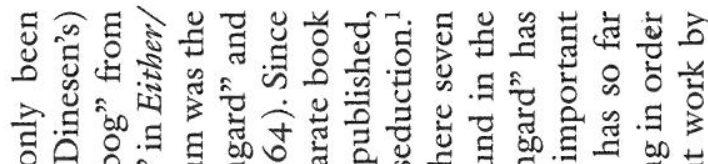

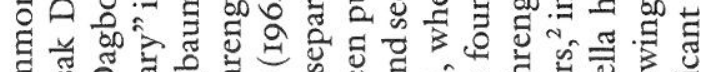

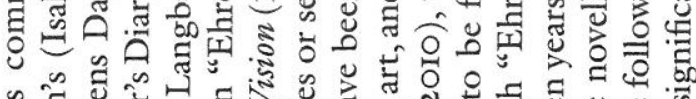

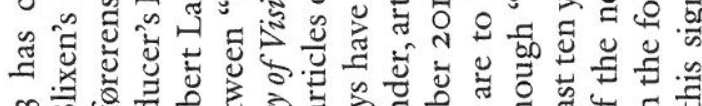

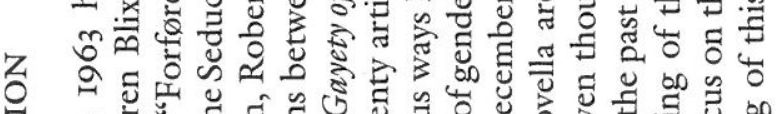

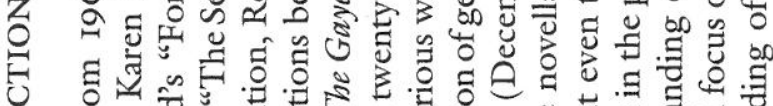

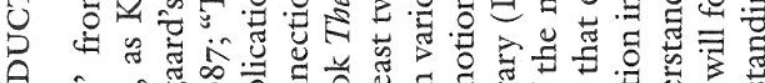

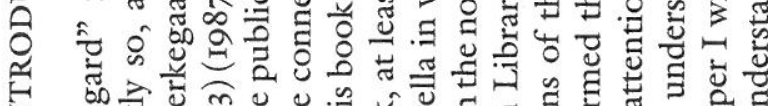

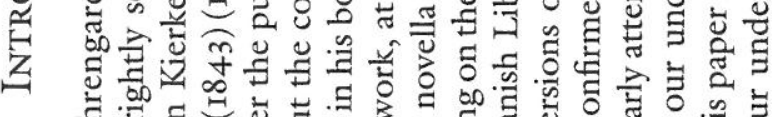

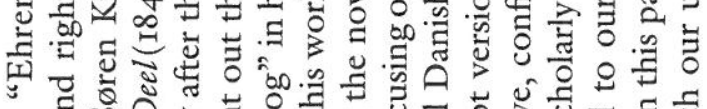

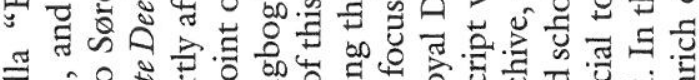
은

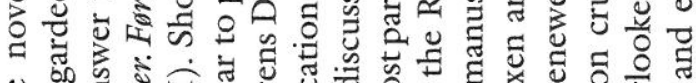

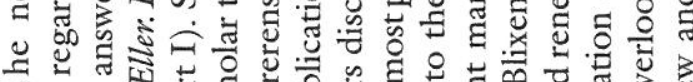

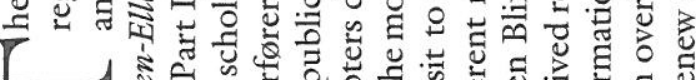

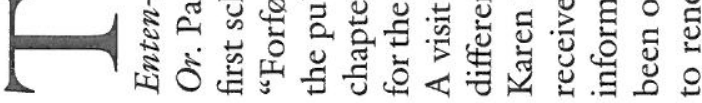
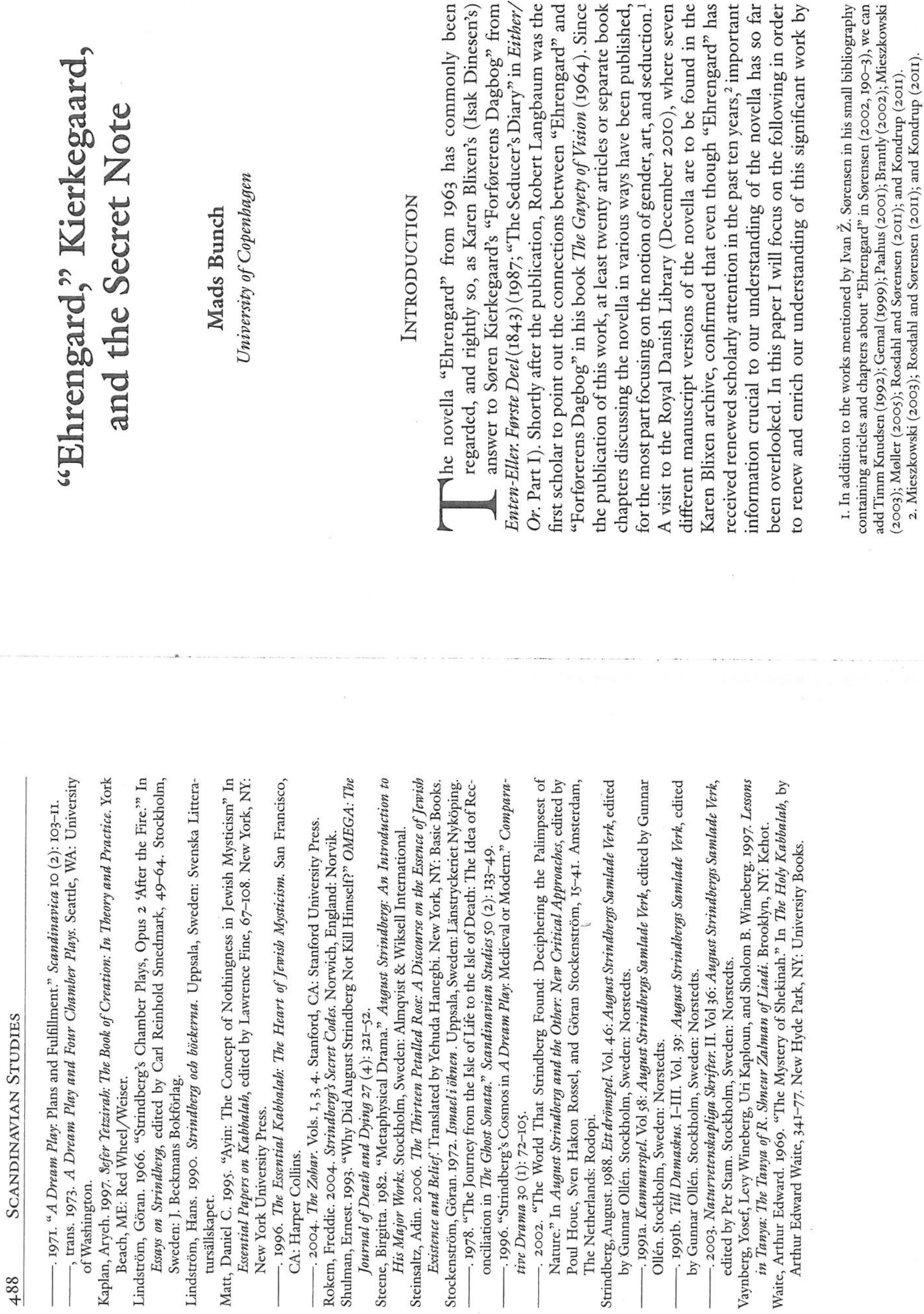


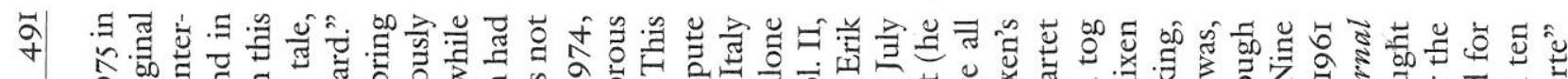

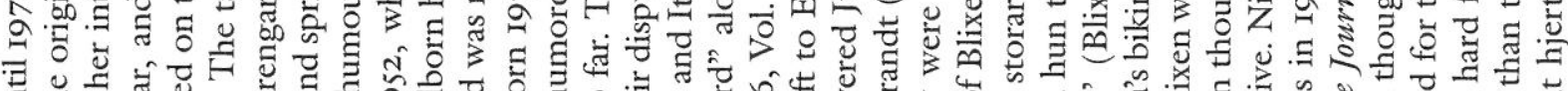

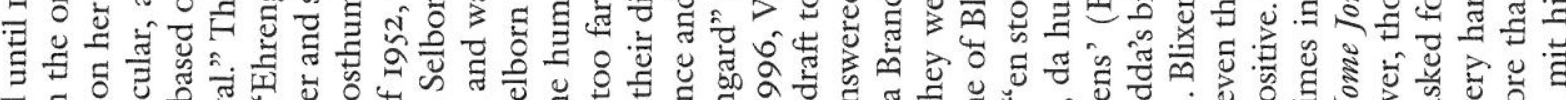

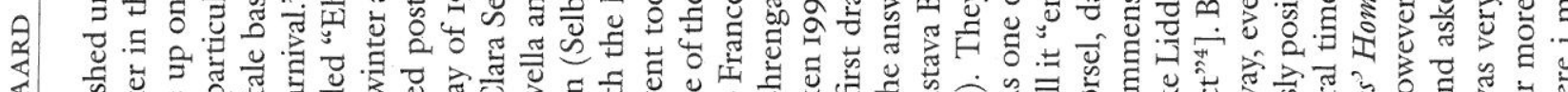

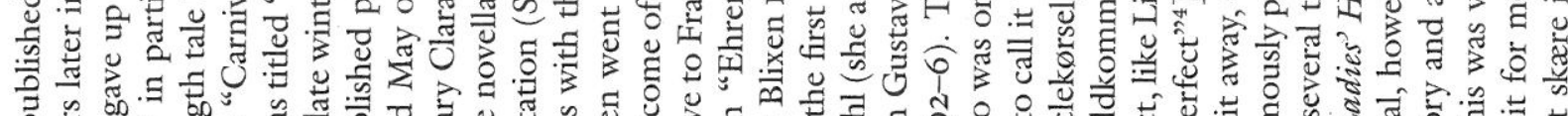

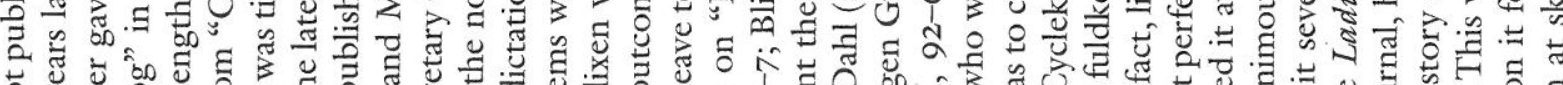

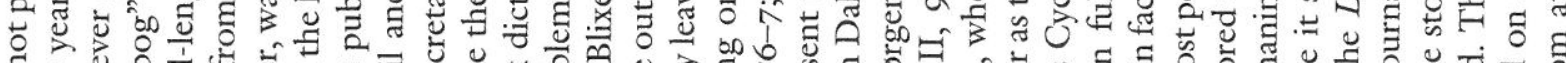

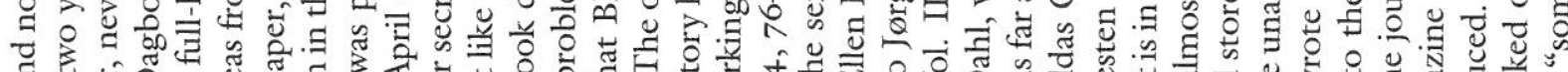

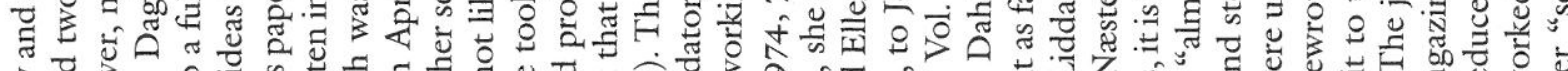

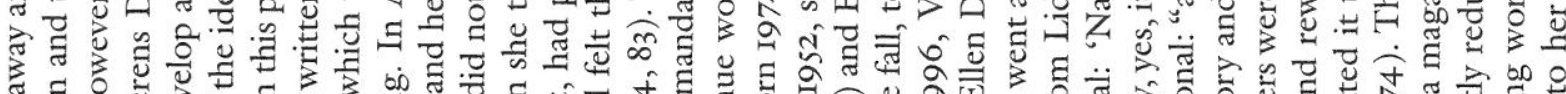

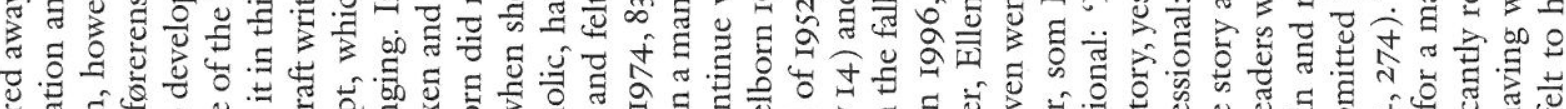

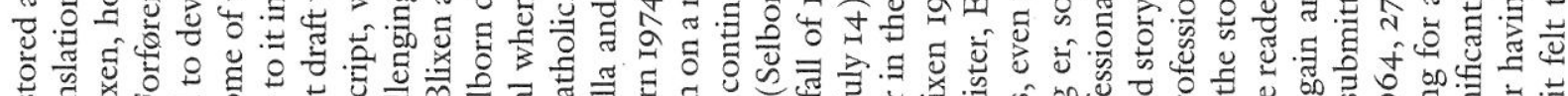

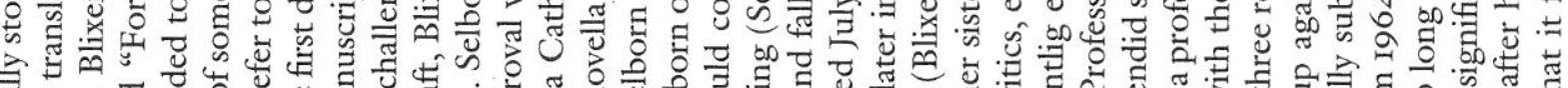

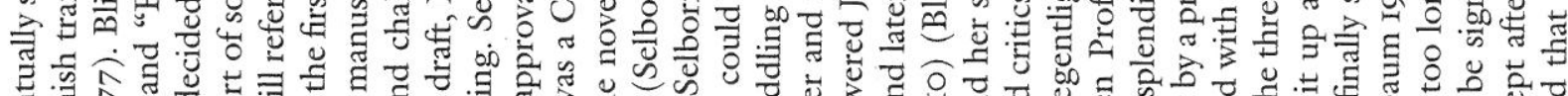

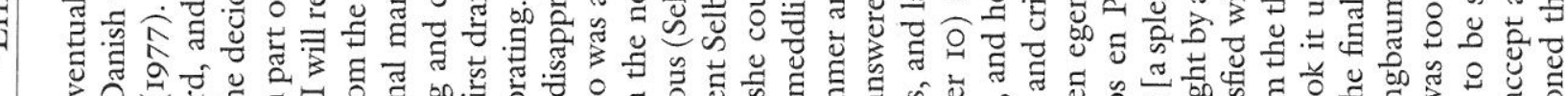

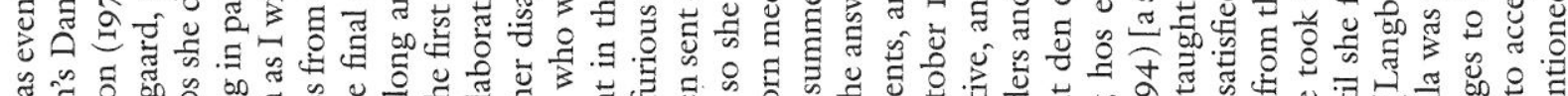

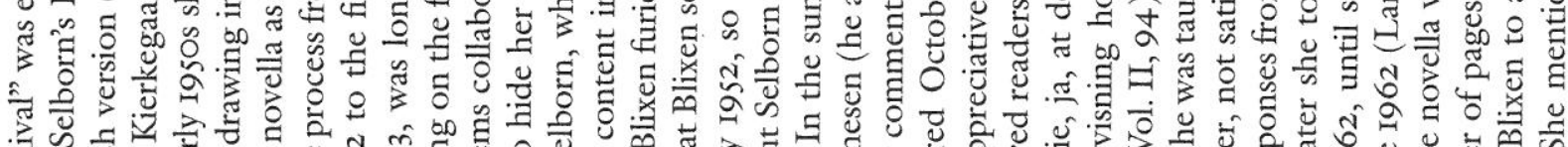

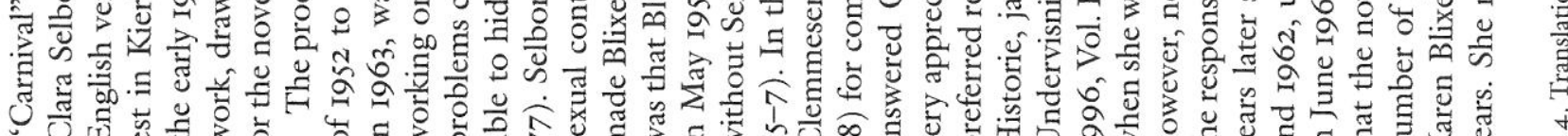

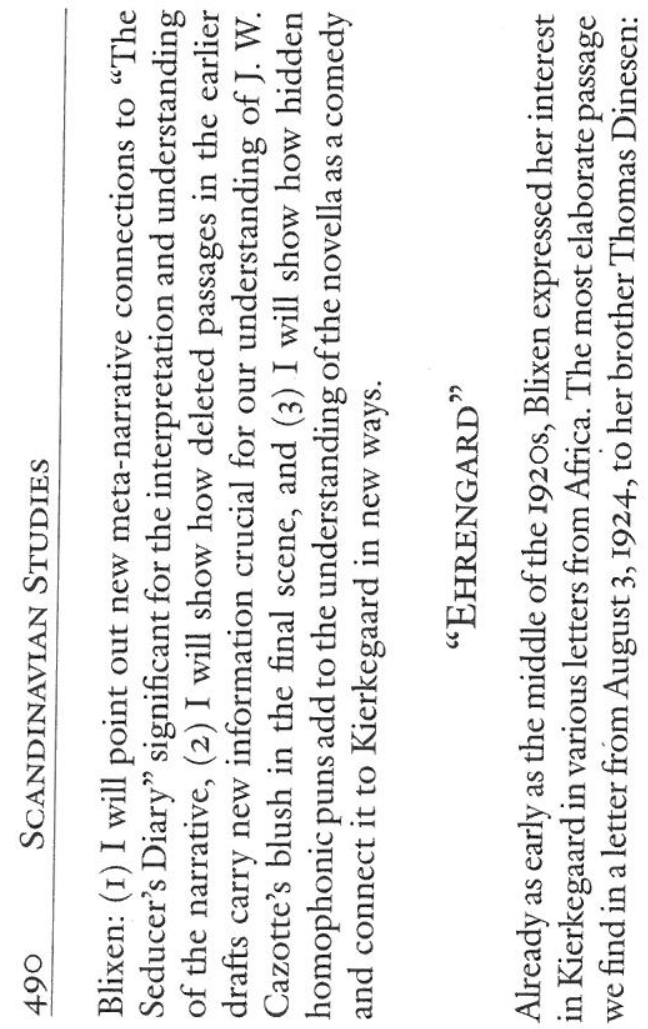

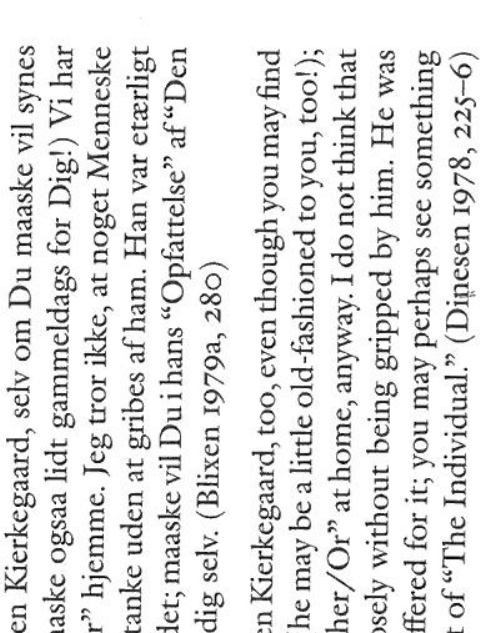

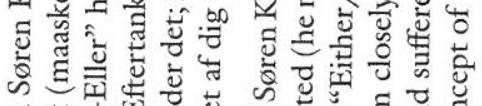

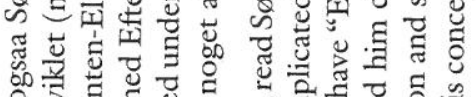

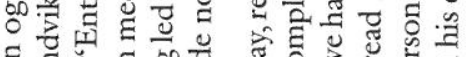

5.

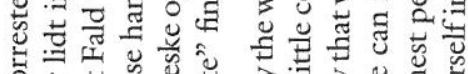

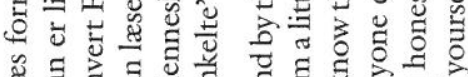

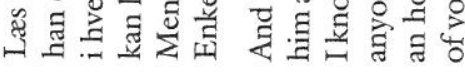

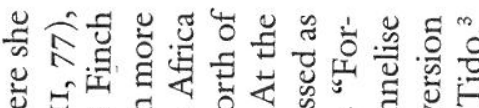

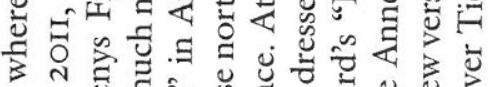

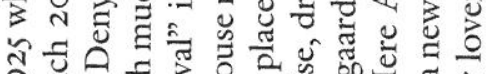

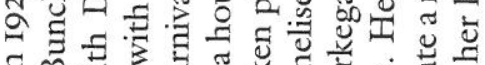

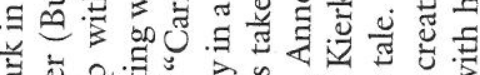
策 政

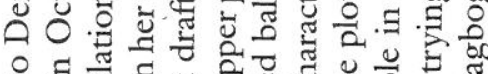

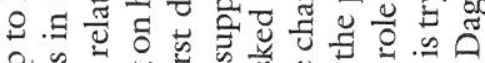

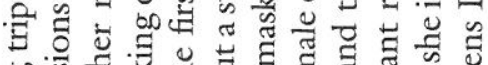

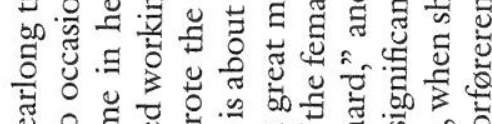

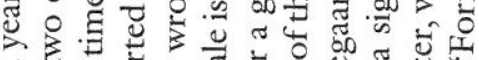

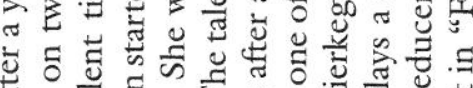

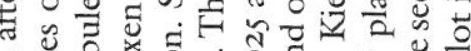

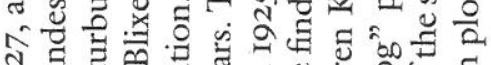
b

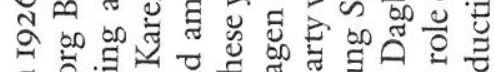

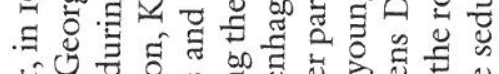

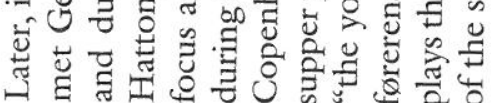

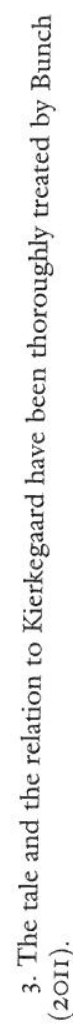




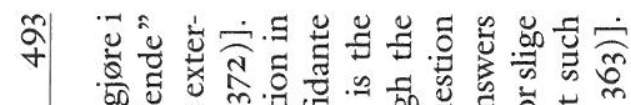

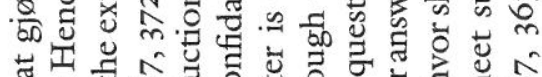

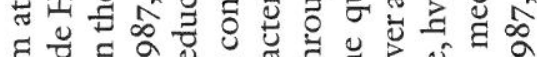

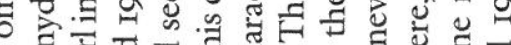

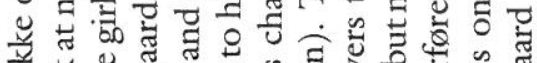

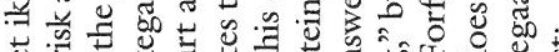

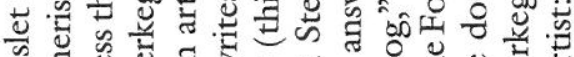
on

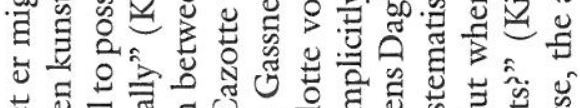

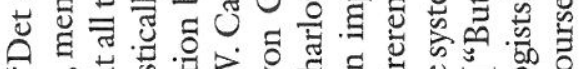

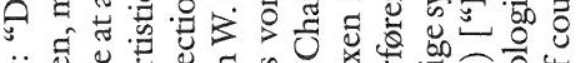

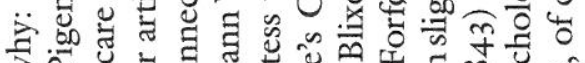

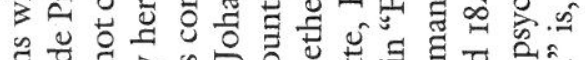

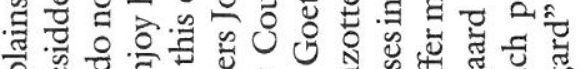

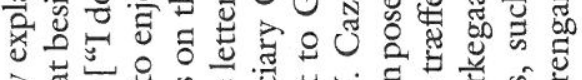

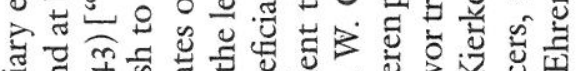

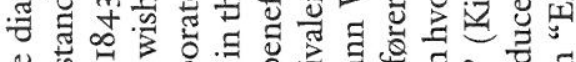

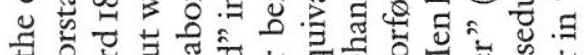

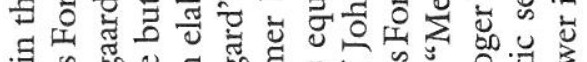

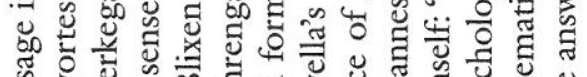

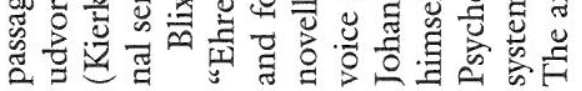

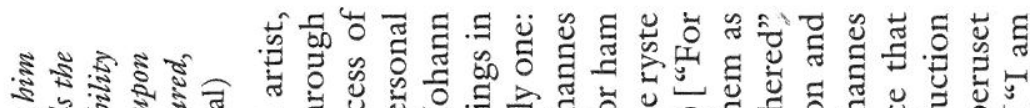

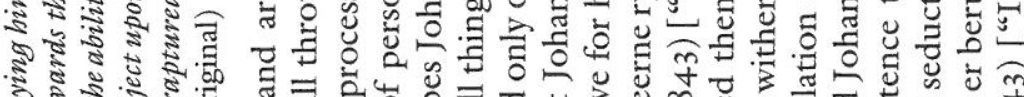
है

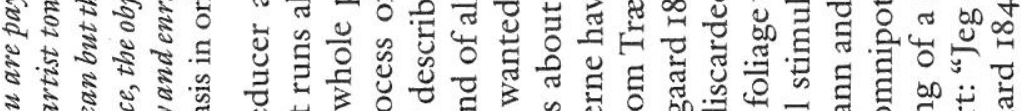
今 ई 논.

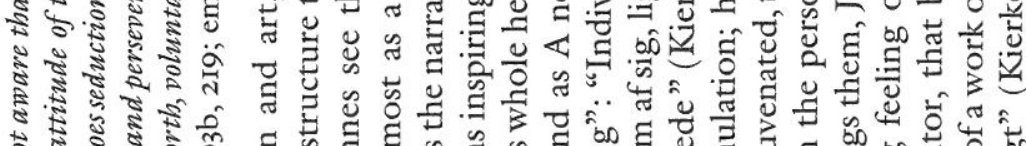

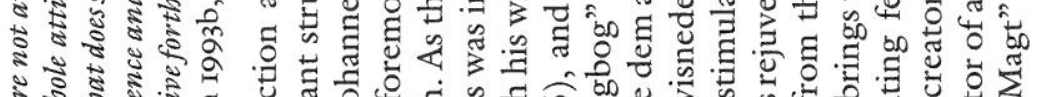
\%

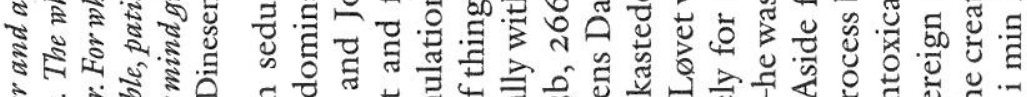
\$ 屯ㄴ. to ช. है क. है

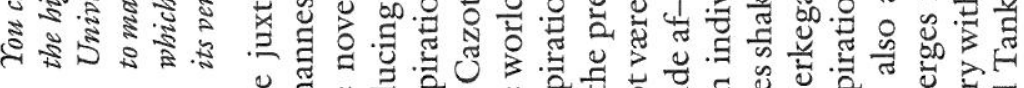

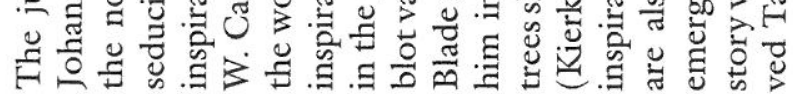

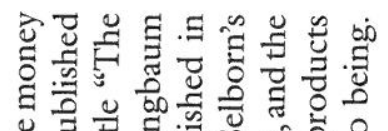

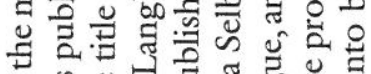

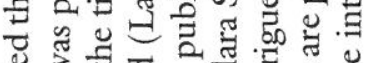

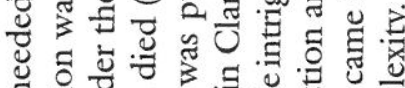

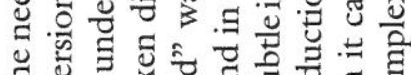

可

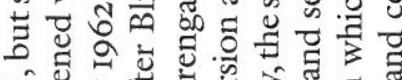

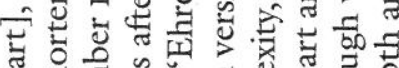

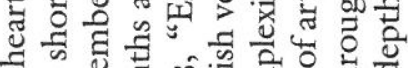

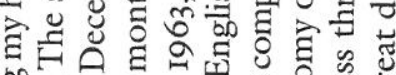

of

整

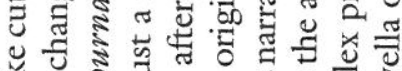

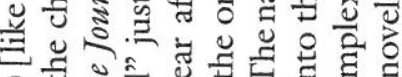

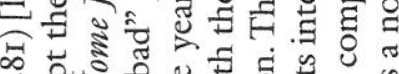

인

of

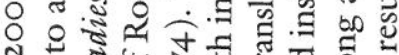

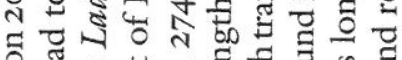

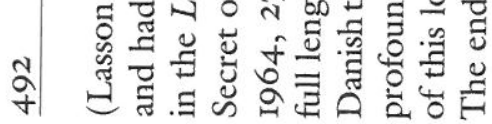

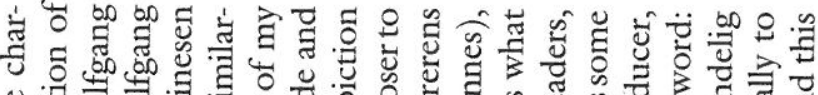

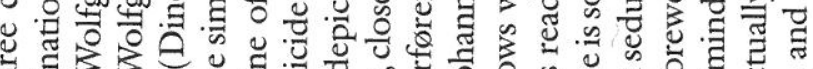

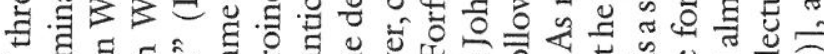

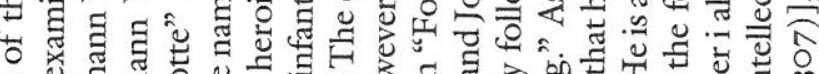
制 웡

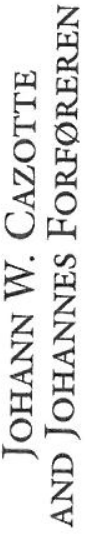

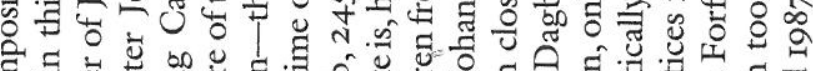

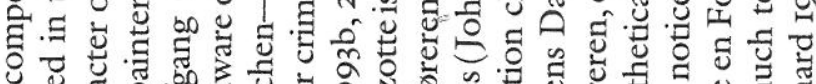

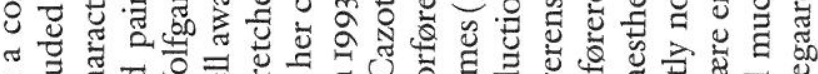

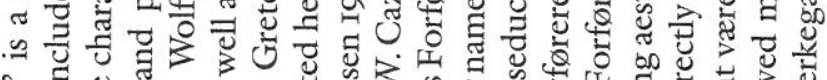

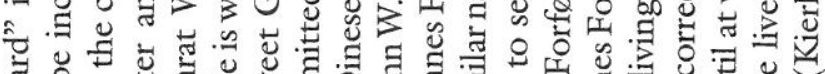

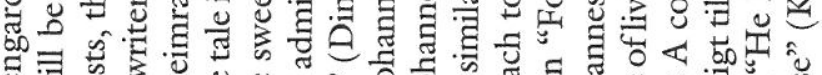

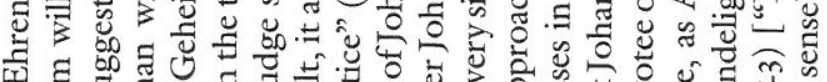

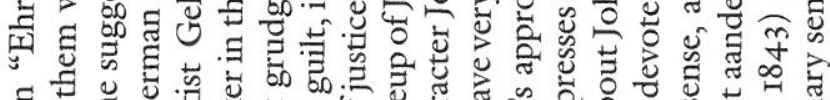

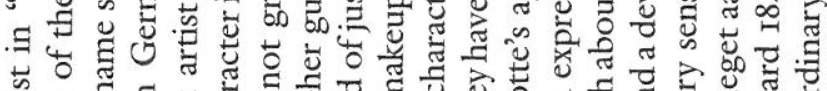

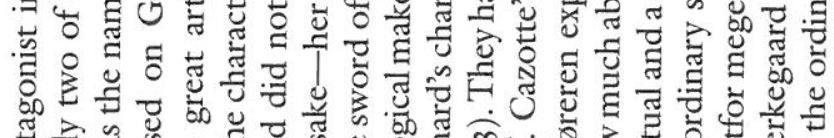

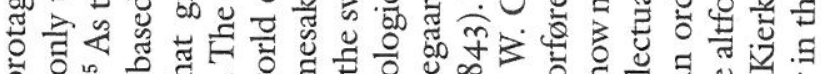

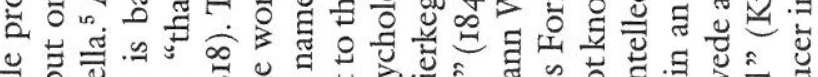

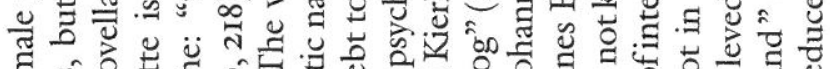

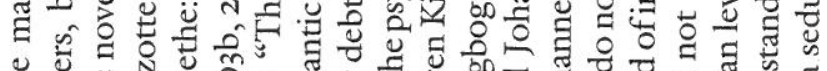

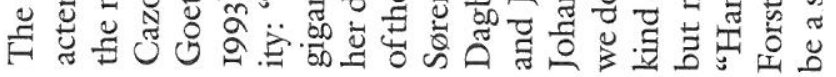

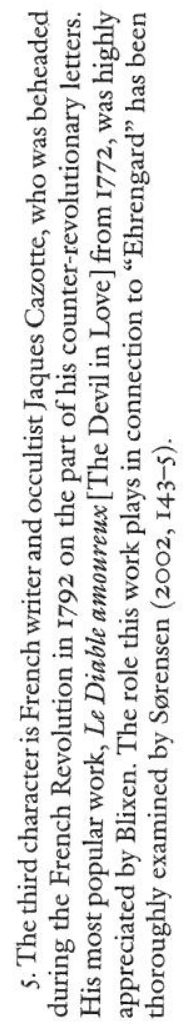



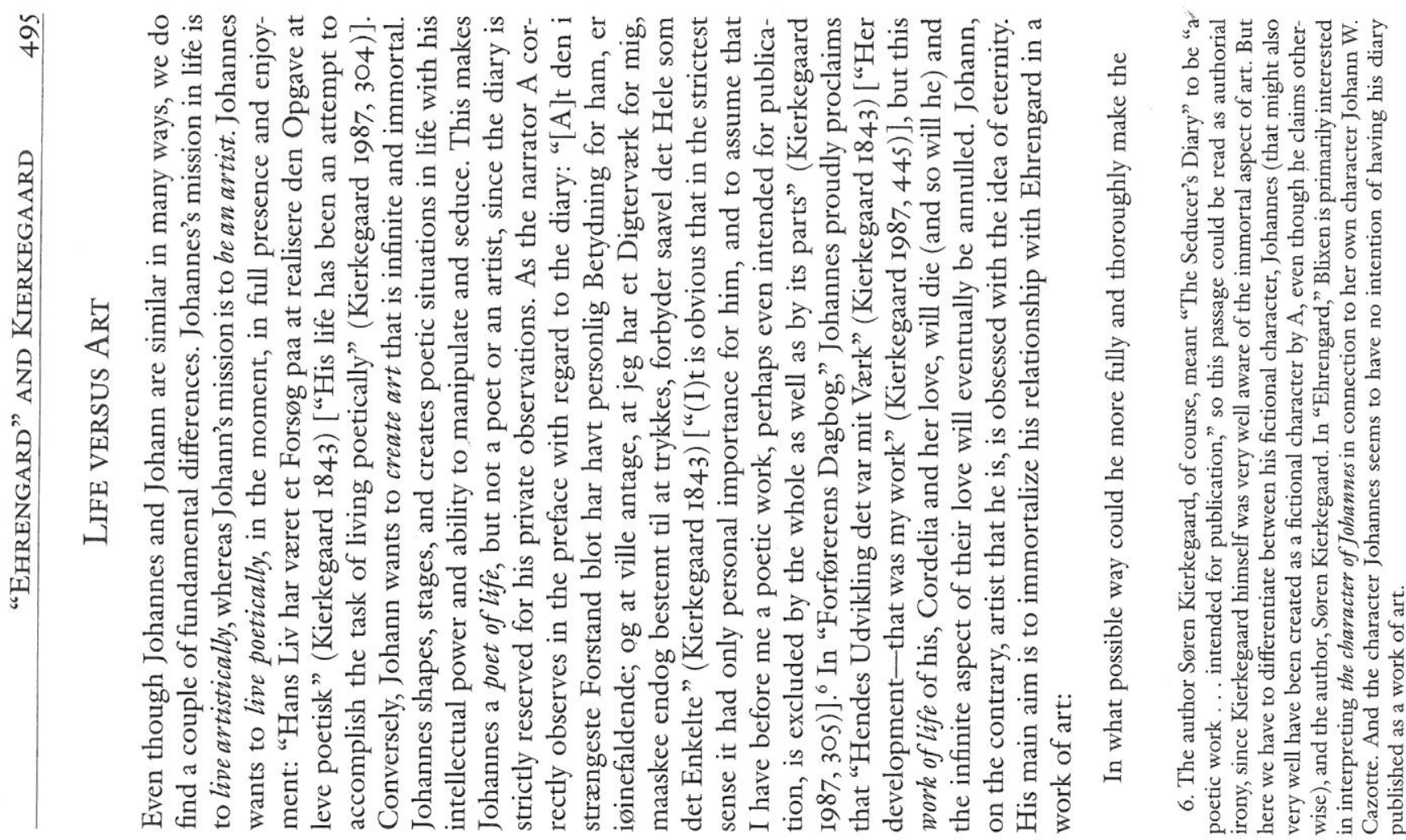

चّ.

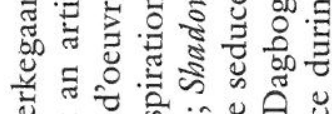

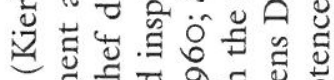

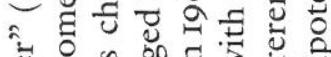

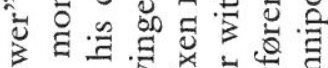

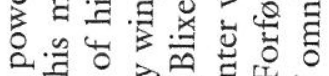

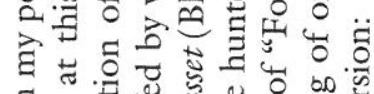

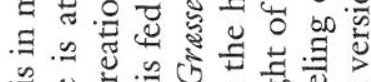

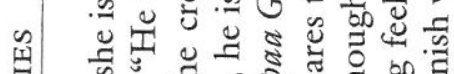

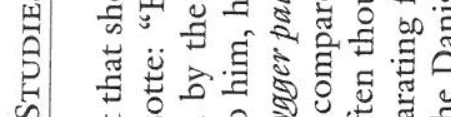

z

द

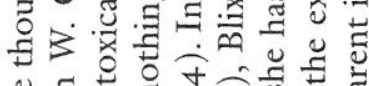

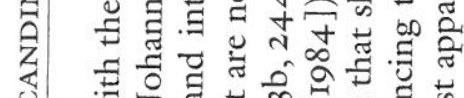

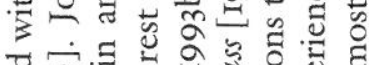

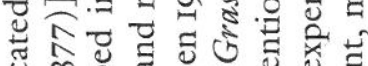

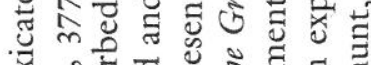

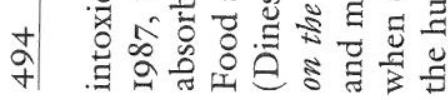

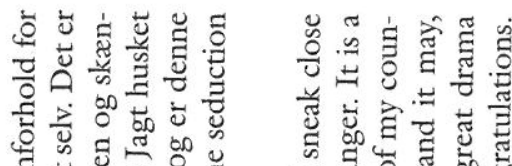

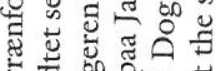

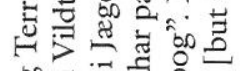

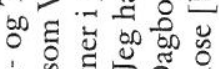

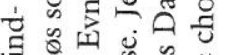

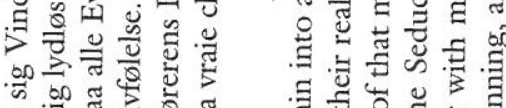

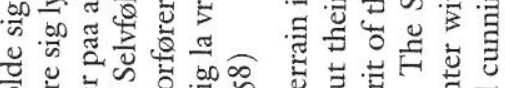

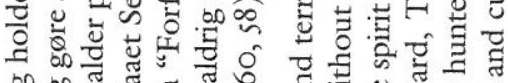

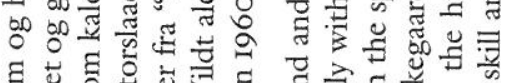

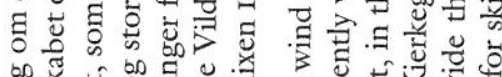

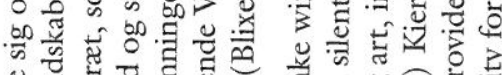

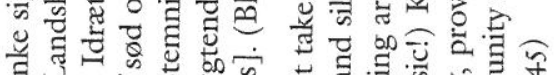

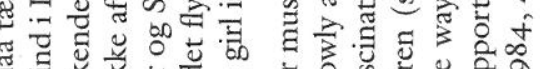

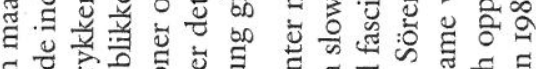

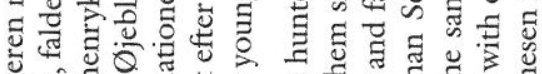

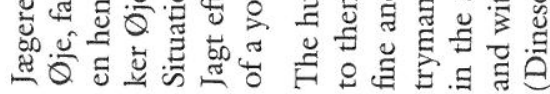

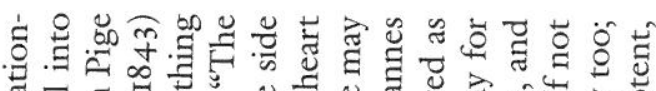

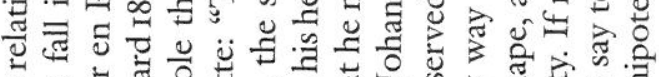

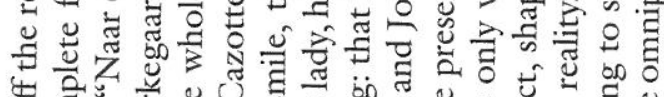

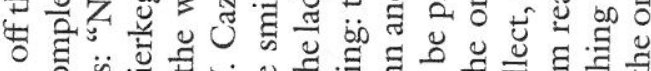

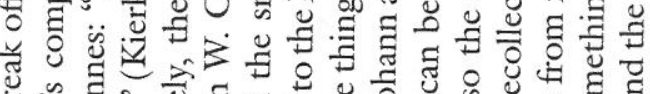

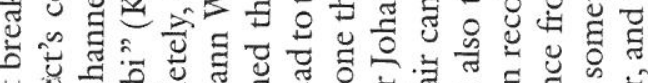

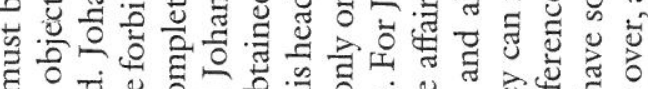

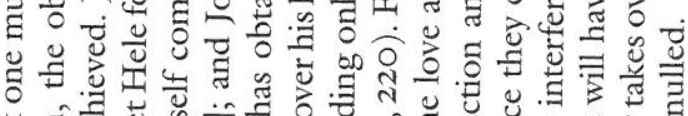

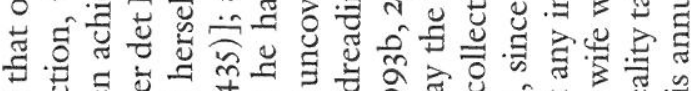
记

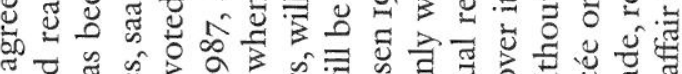

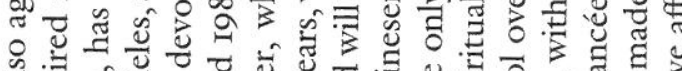

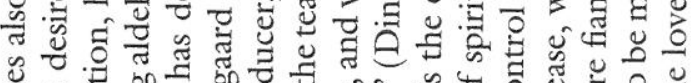

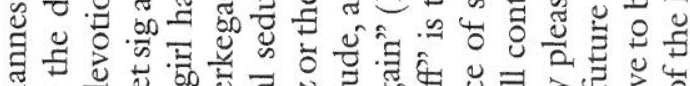

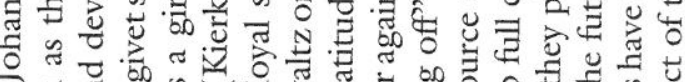

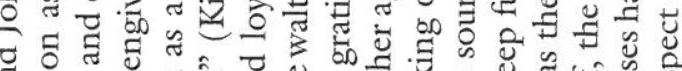
击

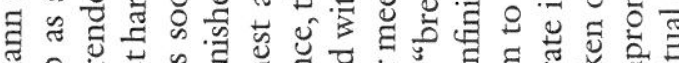

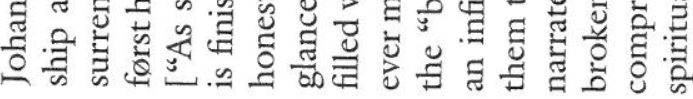



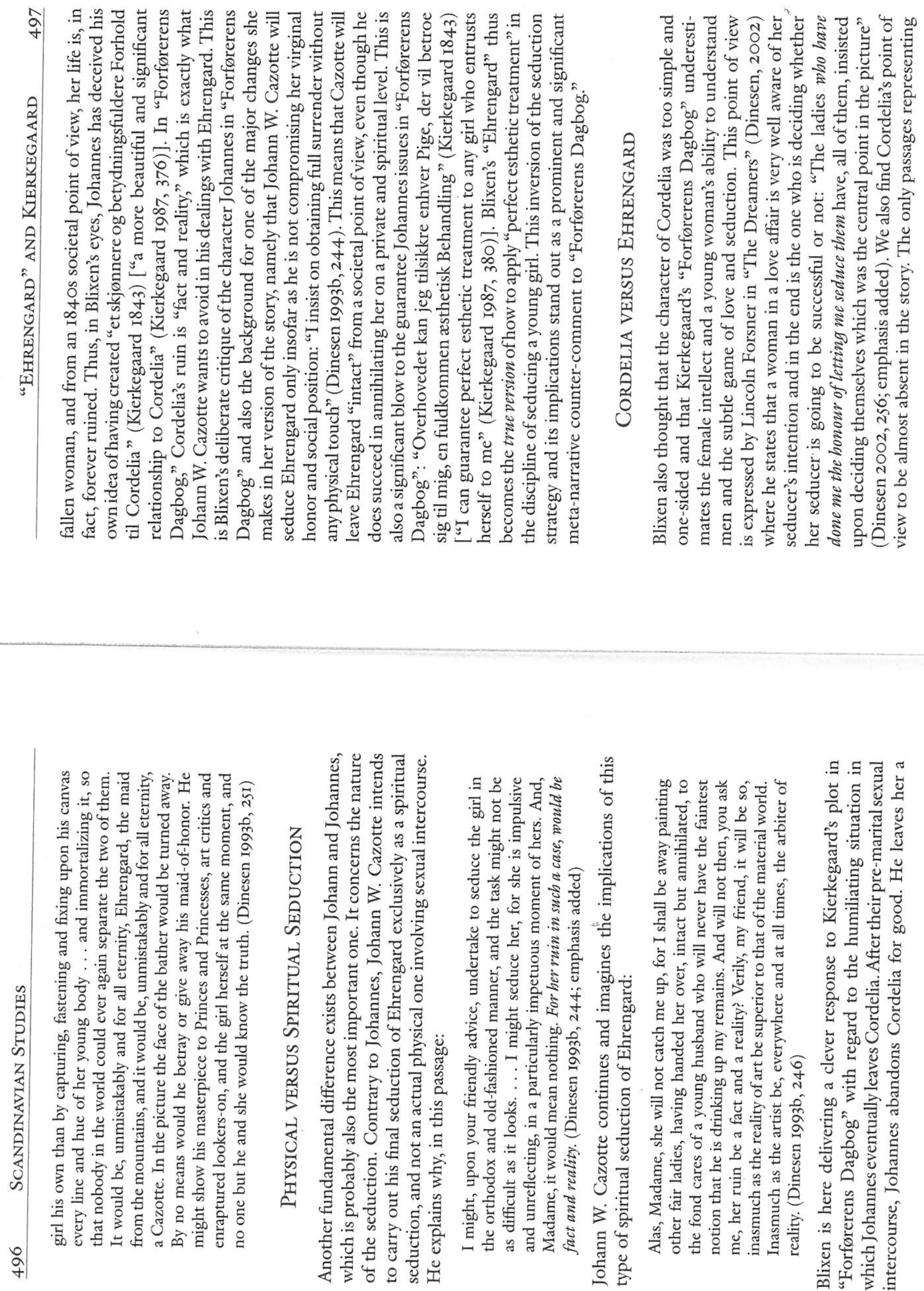

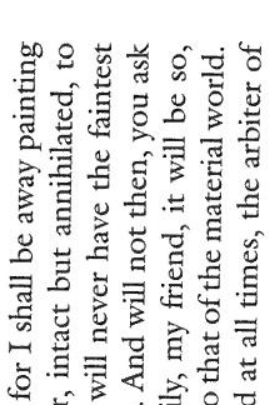

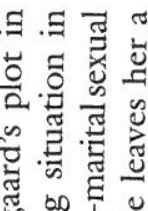

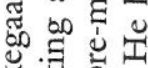

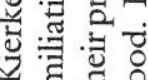

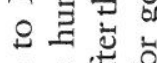

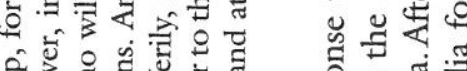

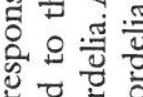

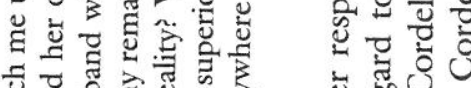

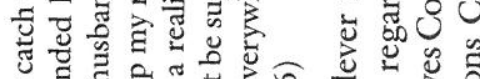

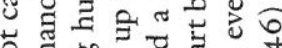

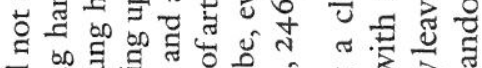

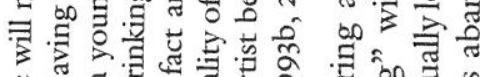

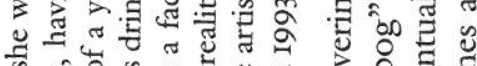

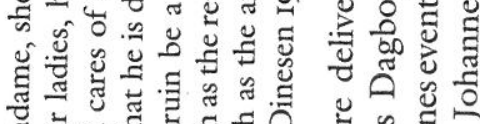

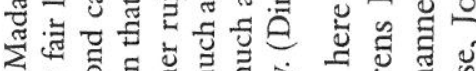

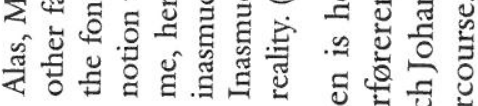

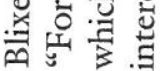




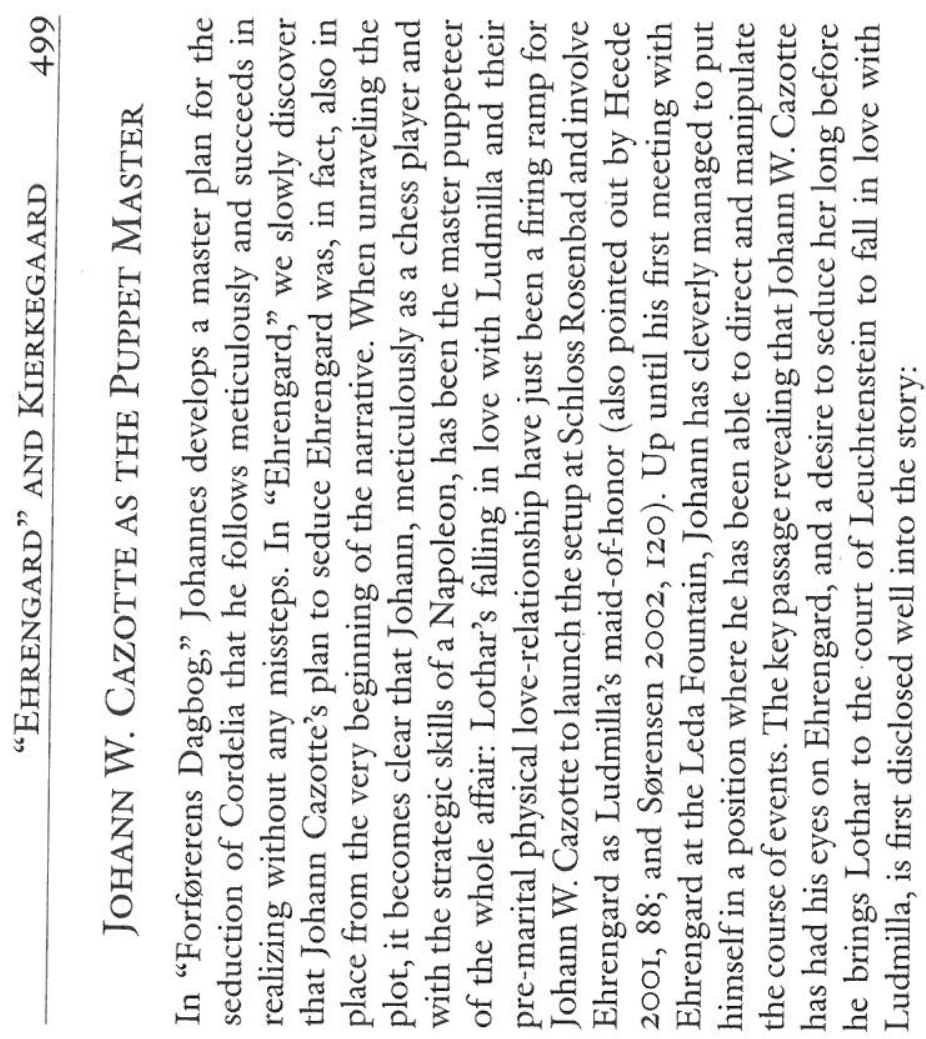

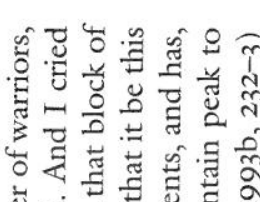

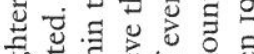

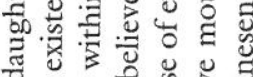

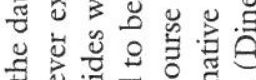

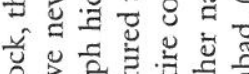

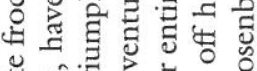

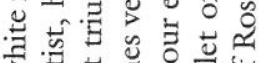

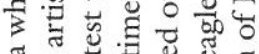

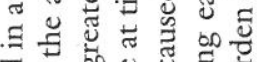

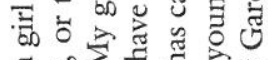
न

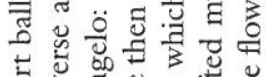

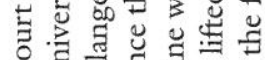

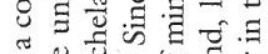

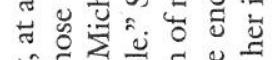

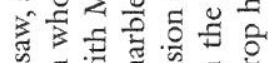

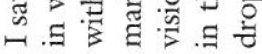

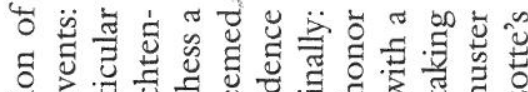

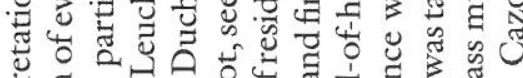

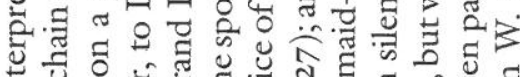
药

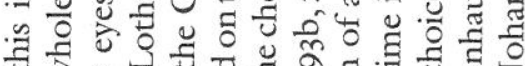
‡

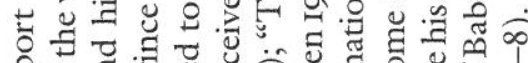

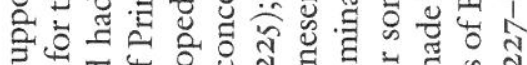
क्ष प्ष

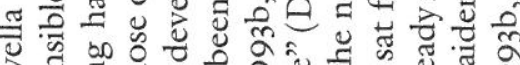
○ั ช

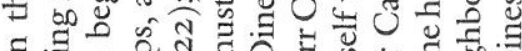

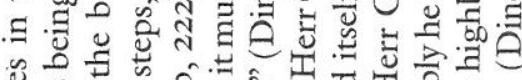

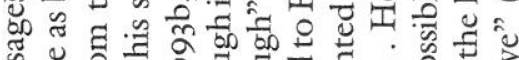

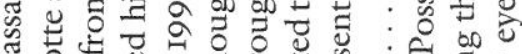

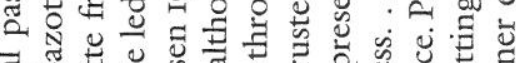
ज़

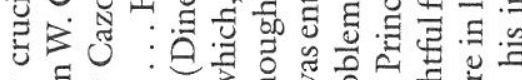

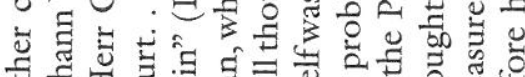

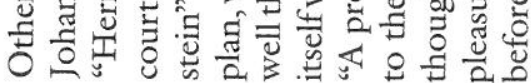

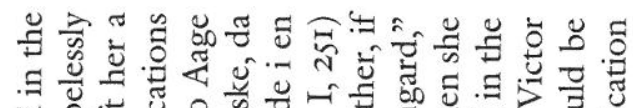

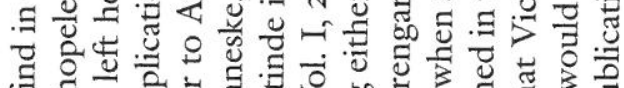

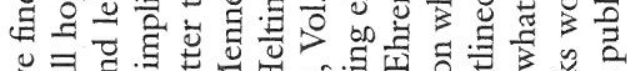

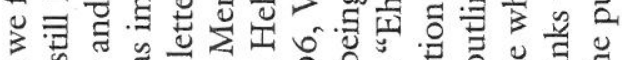
ڤ.

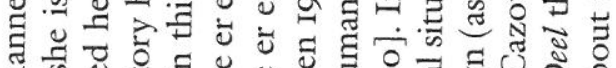

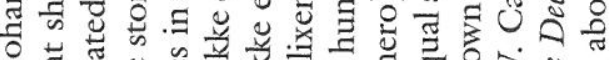

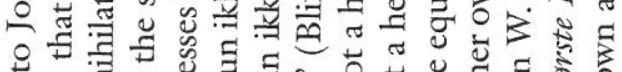

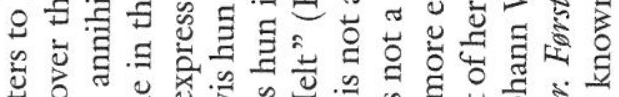

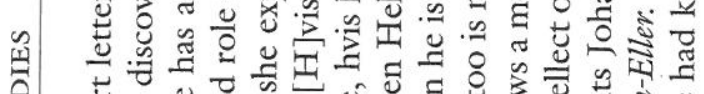

究

की o. :0

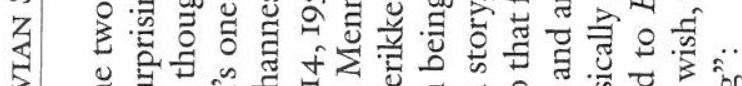

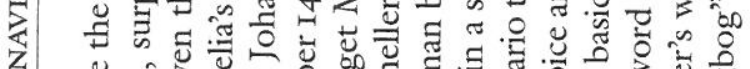

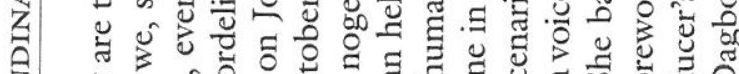

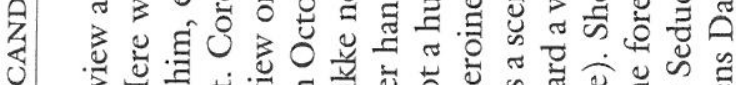

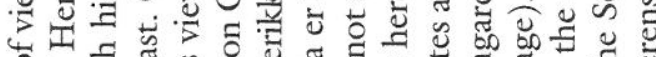

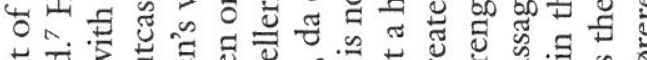

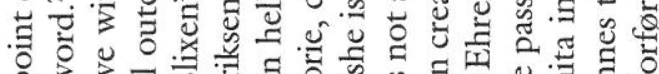

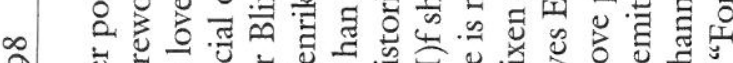

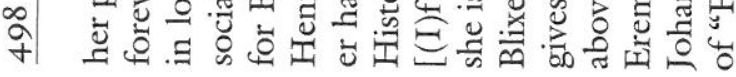

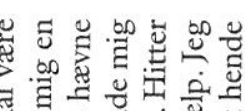

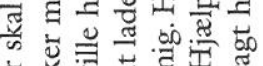

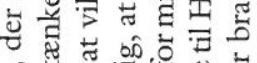

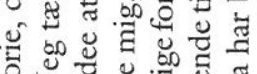

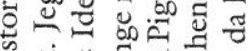

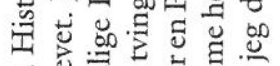

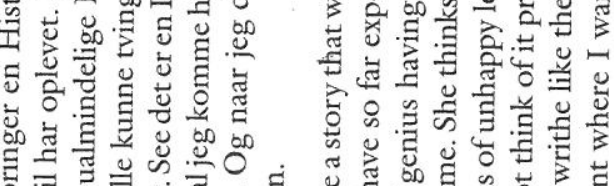

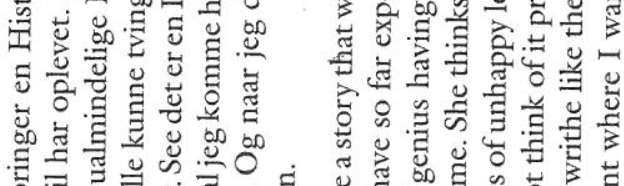

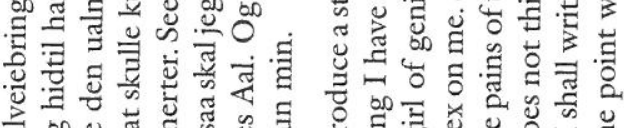

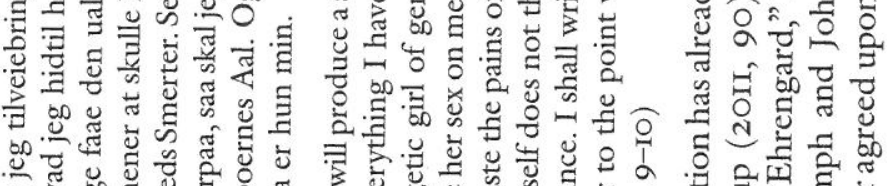

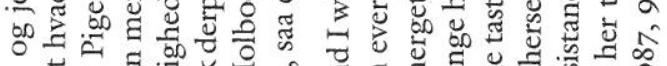

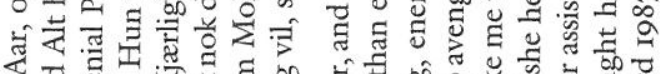

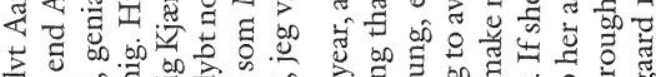

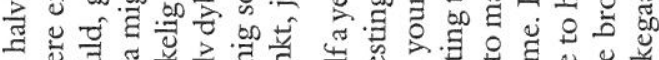

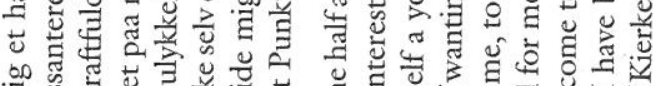

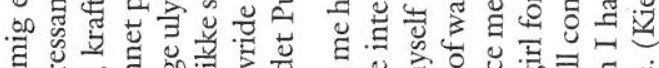

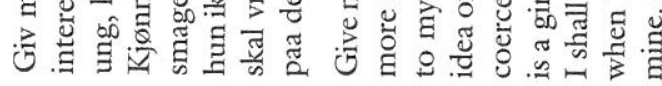

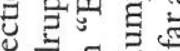

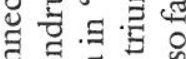
\% 政 을

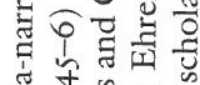

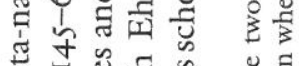
音

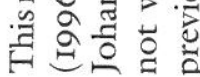

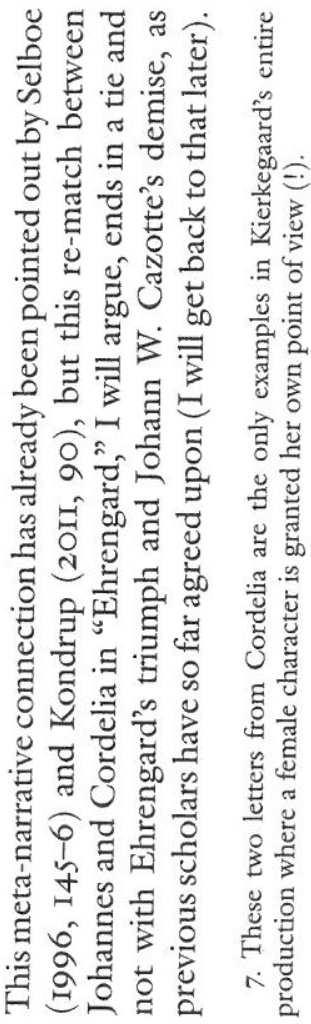



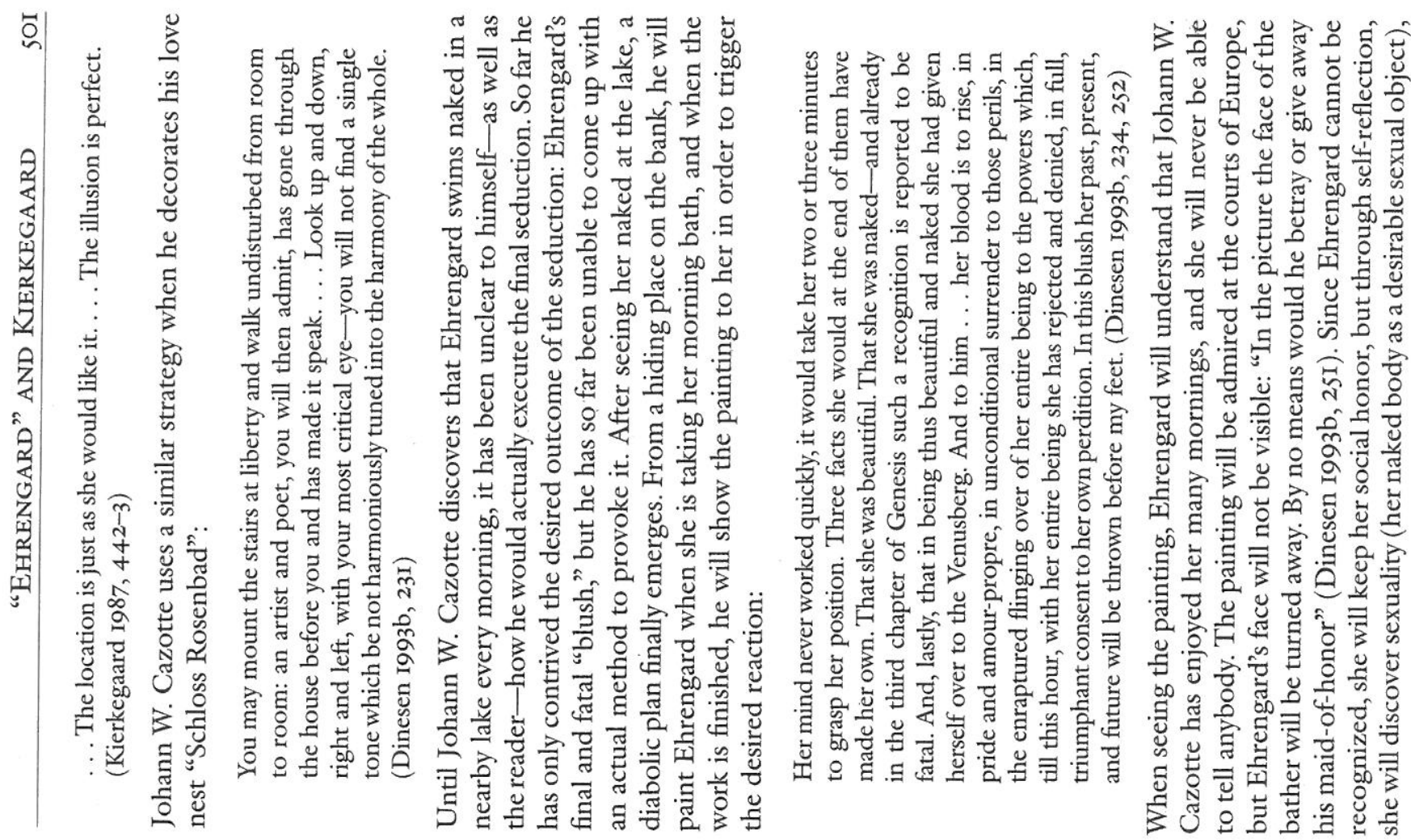

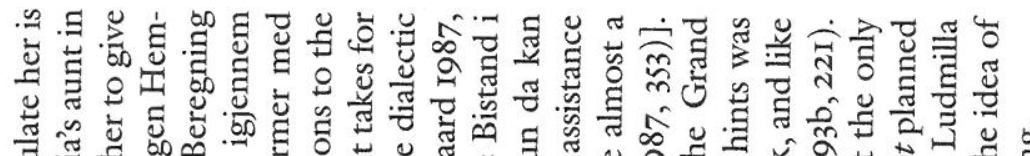

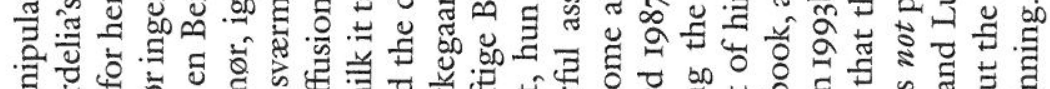

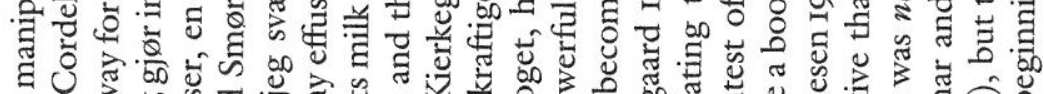

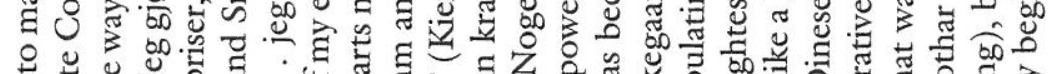

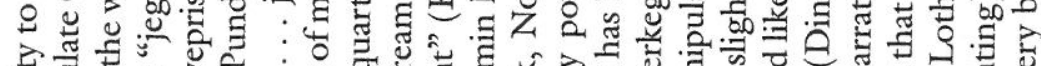

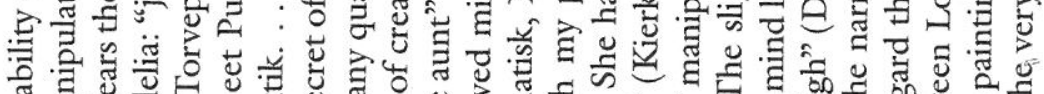

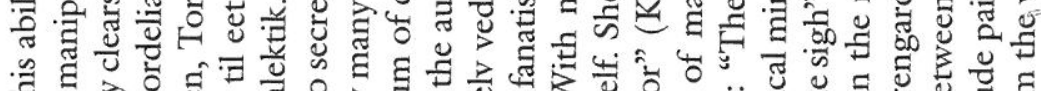

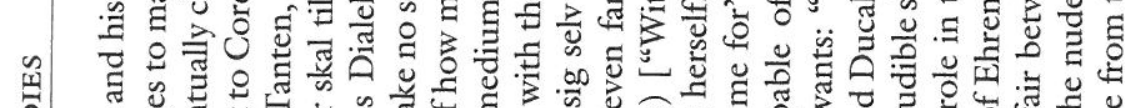

月 क

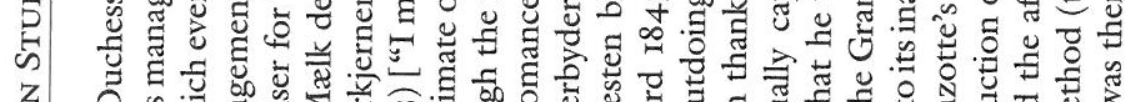

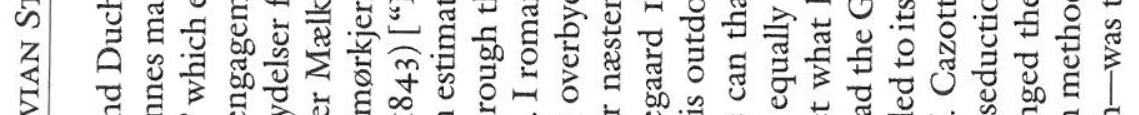

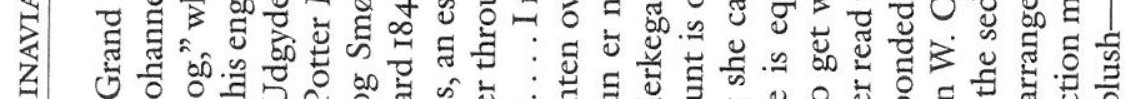

药

出

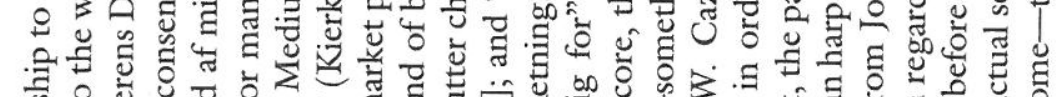

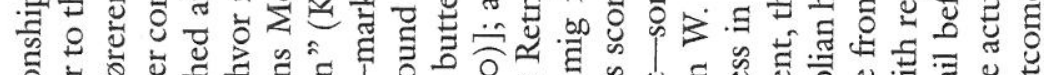

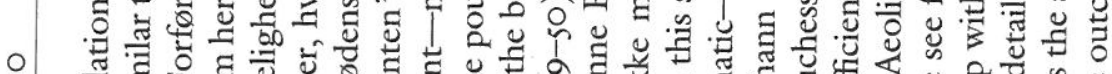

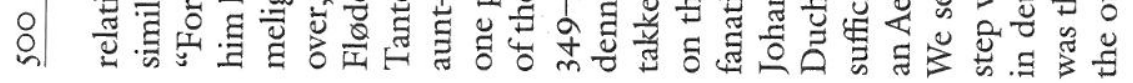

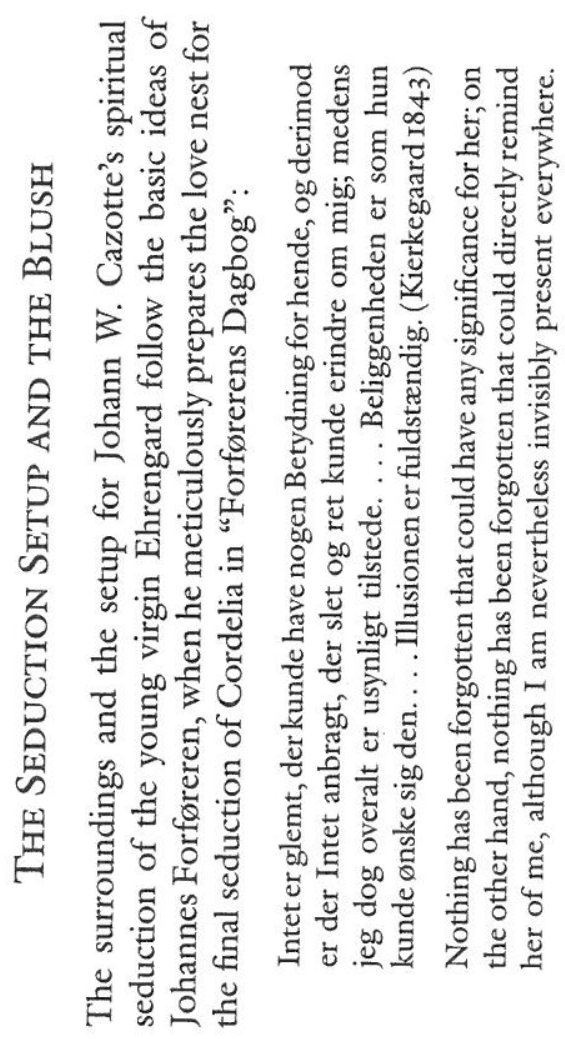



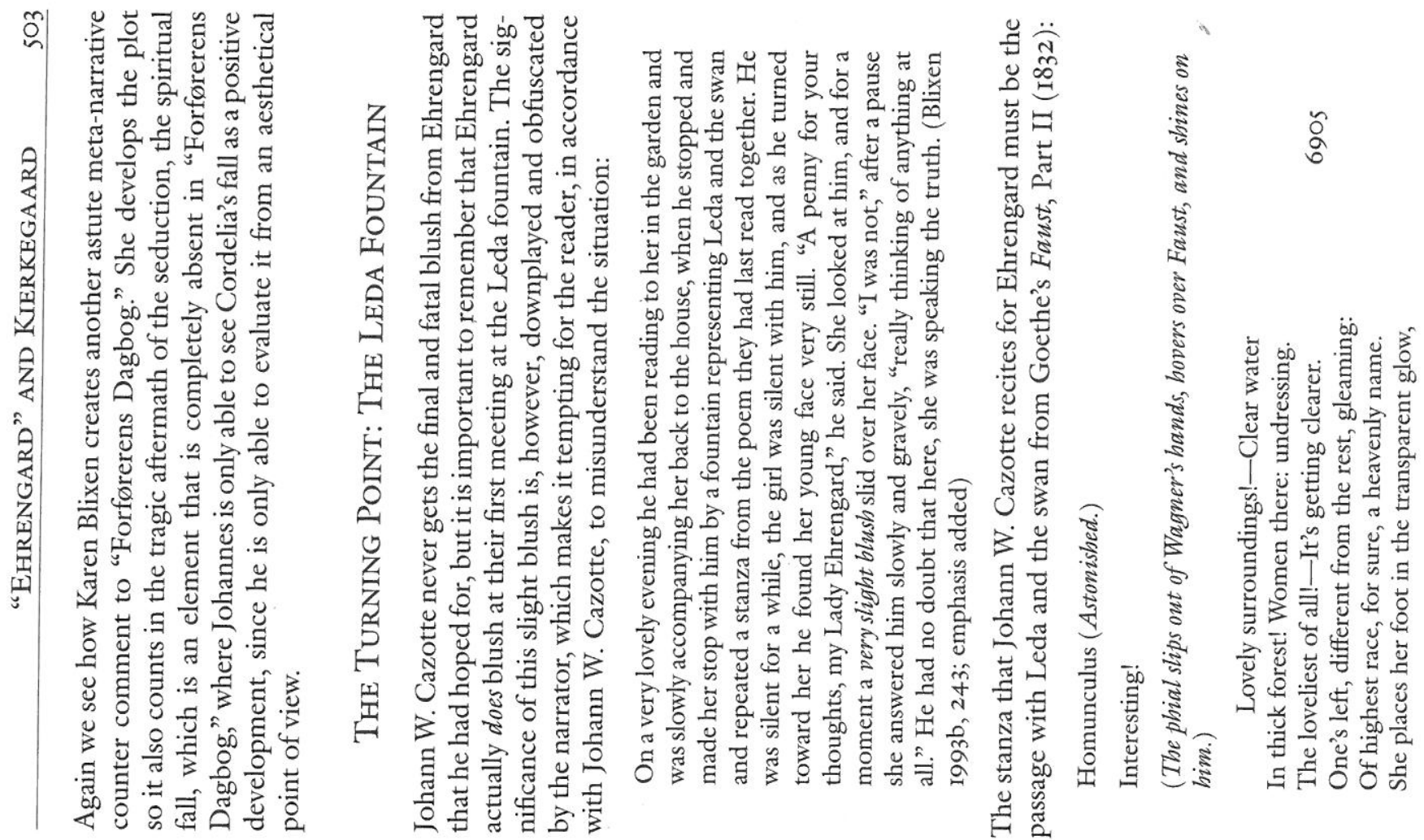

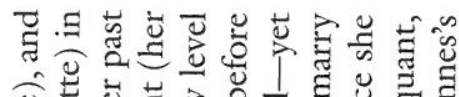

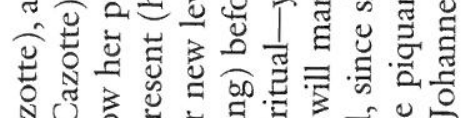

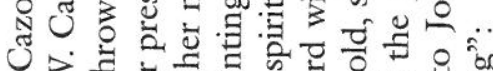

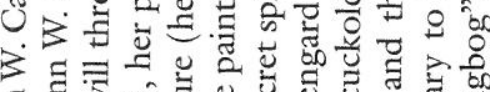

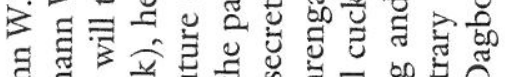

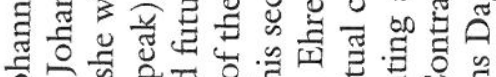

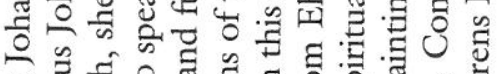

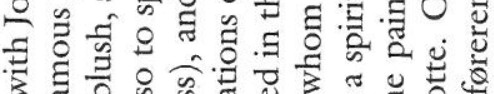

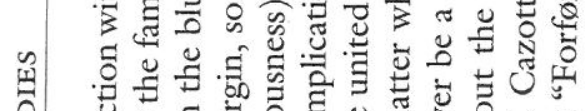

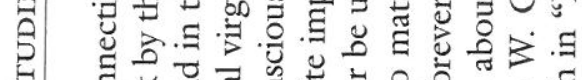

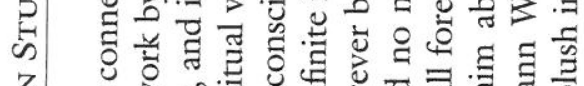

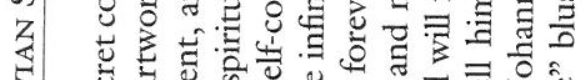

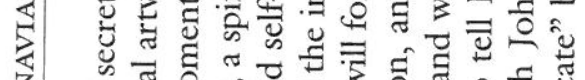

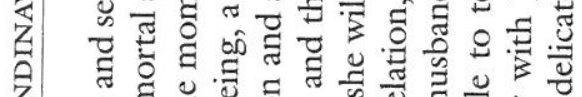

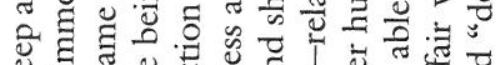

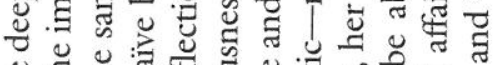

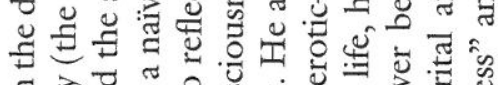

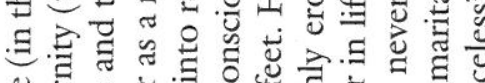

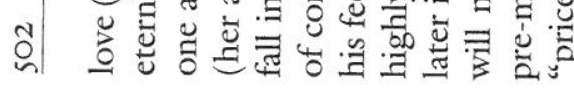

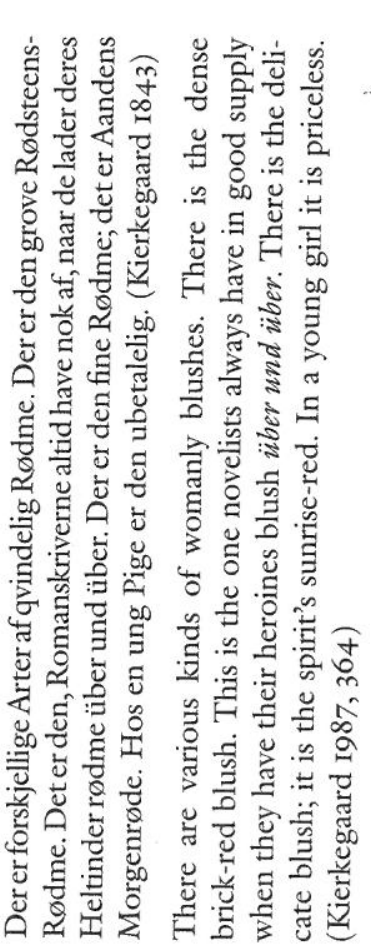

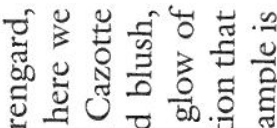

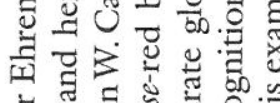

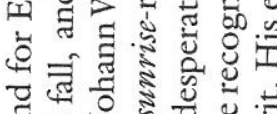

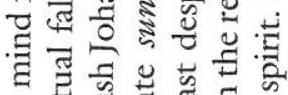

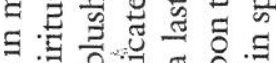

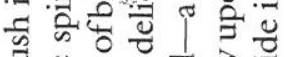

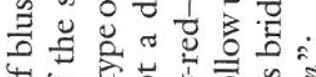

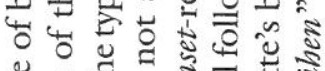

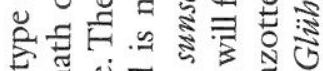

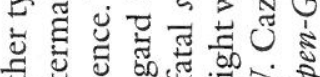

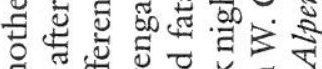

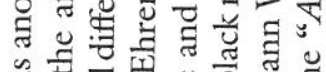

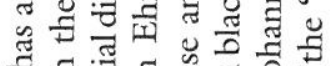

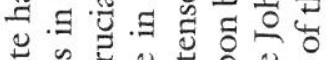

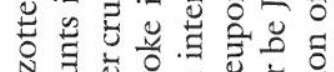

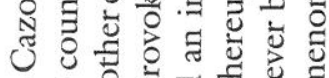

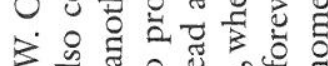

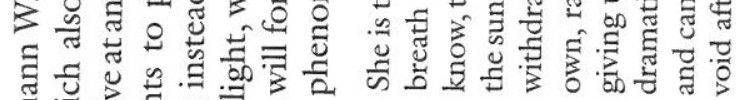

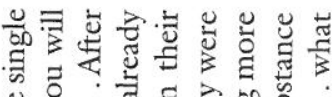

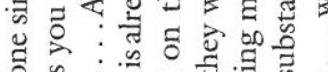

월

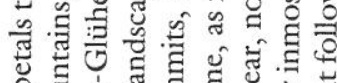

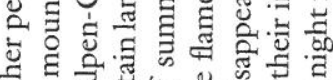

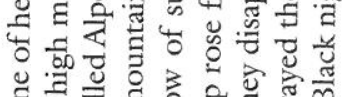

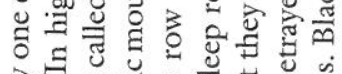

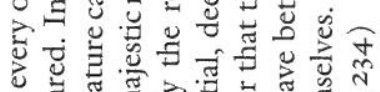

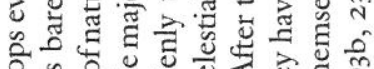

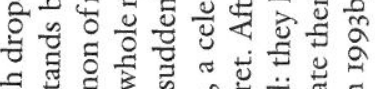

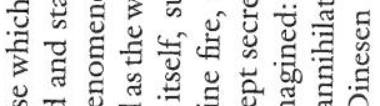

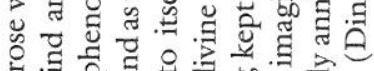

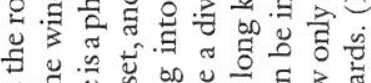

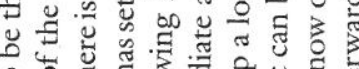

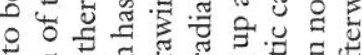

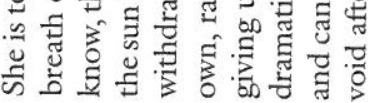

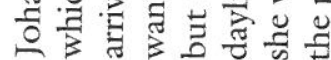




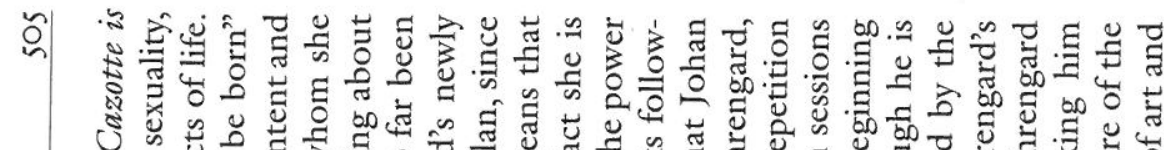

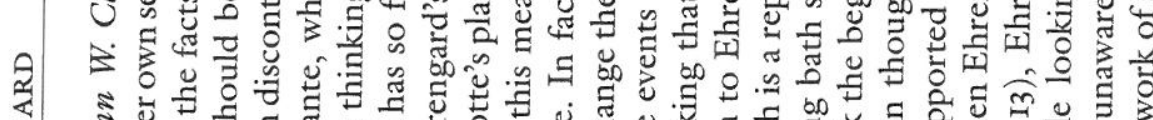

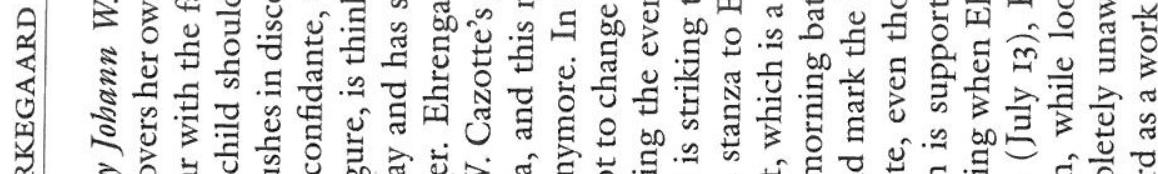

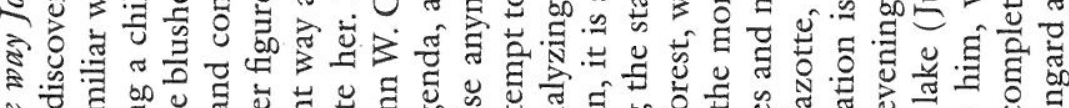

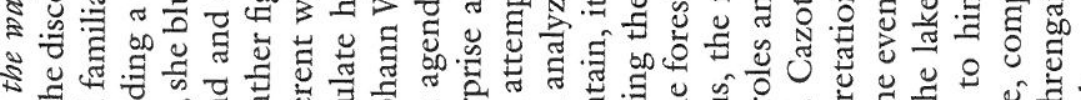
so

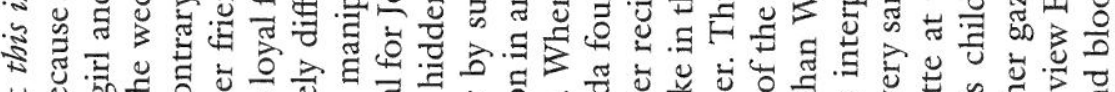

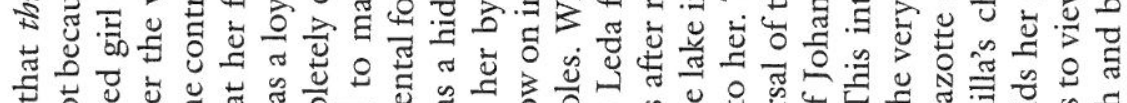

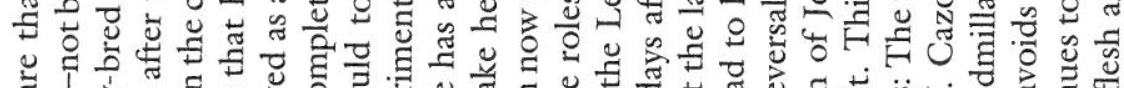

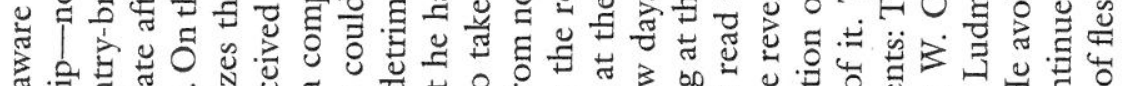

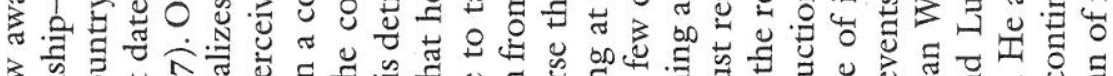

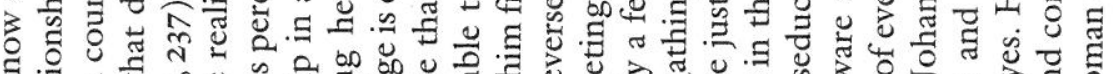

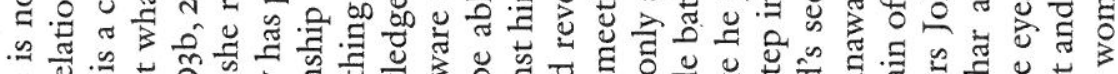

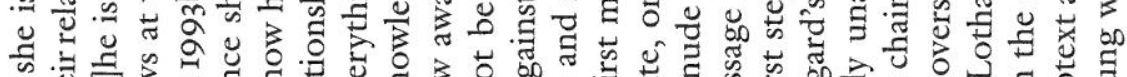

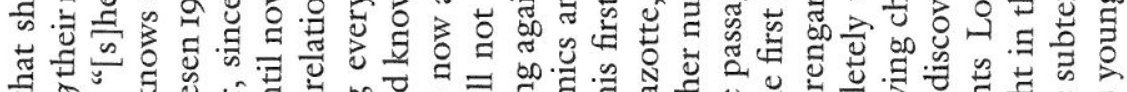

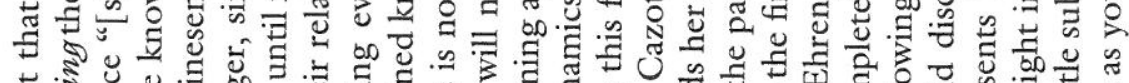

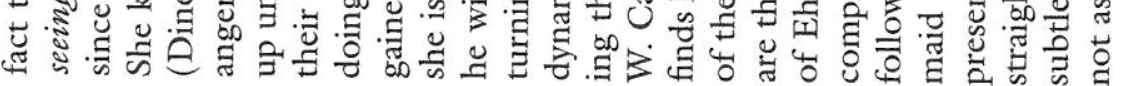

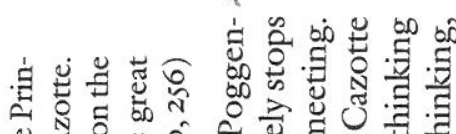

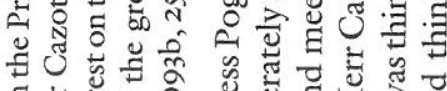

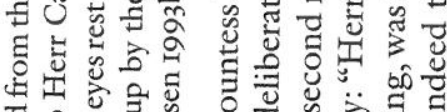

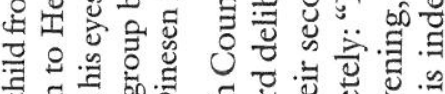

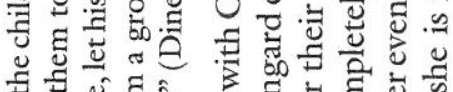

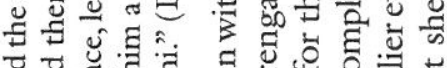

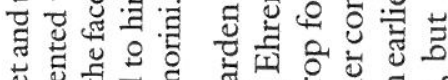

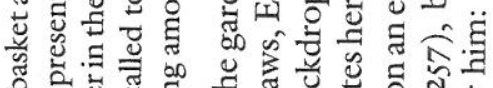

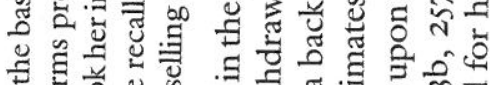

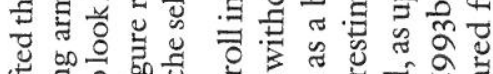

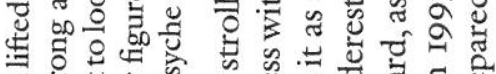

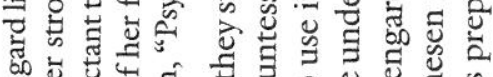
尊总记

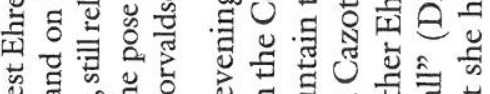

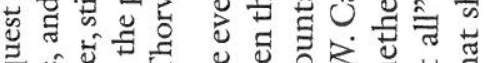

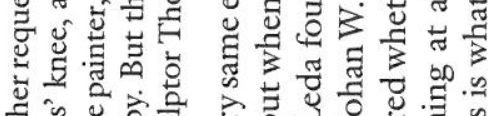

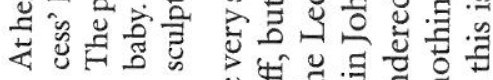

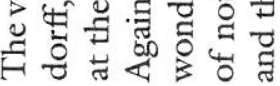

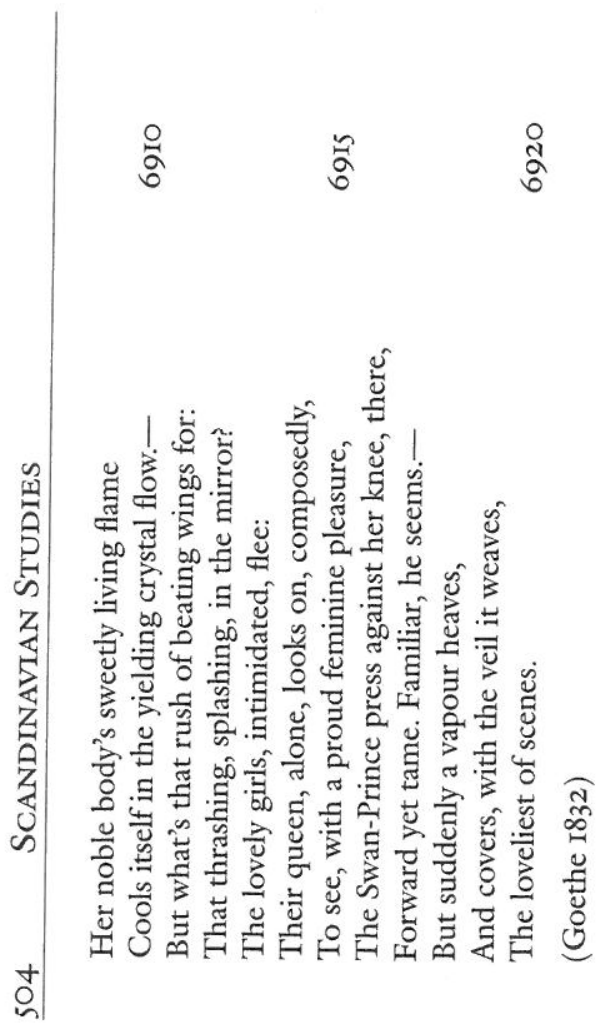

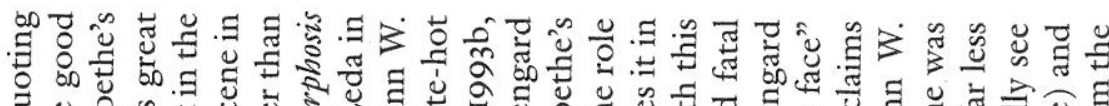

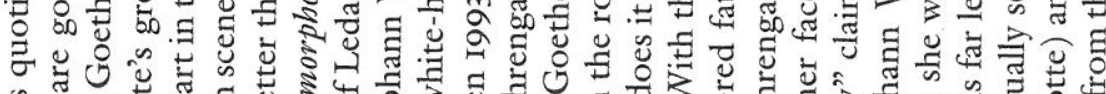

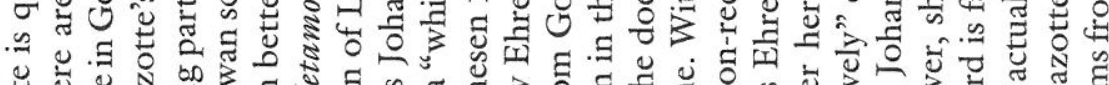

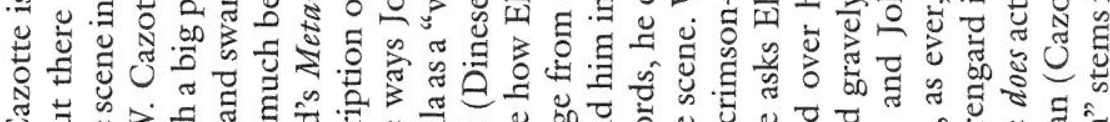
O을

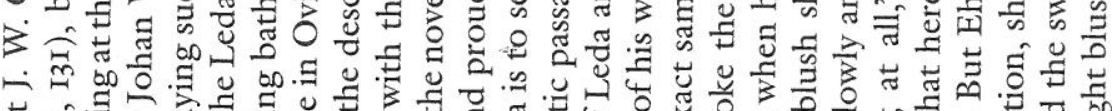

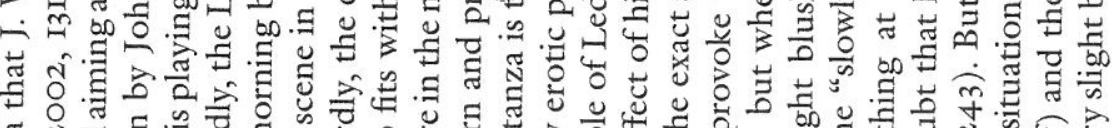

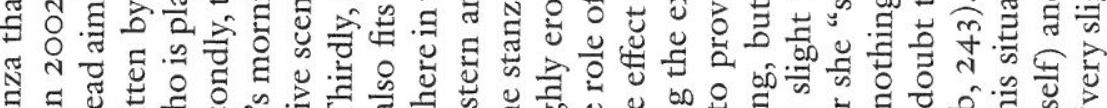

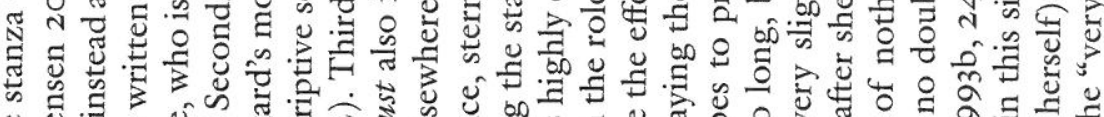
g y o

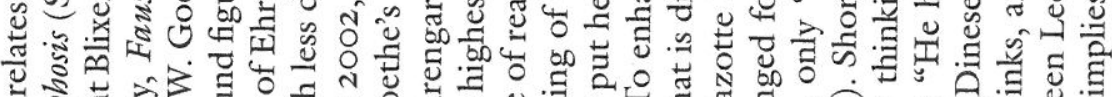

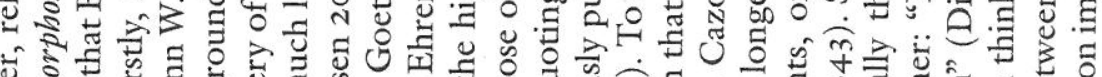

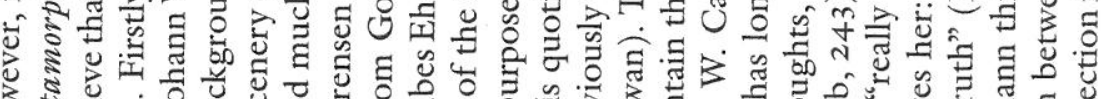

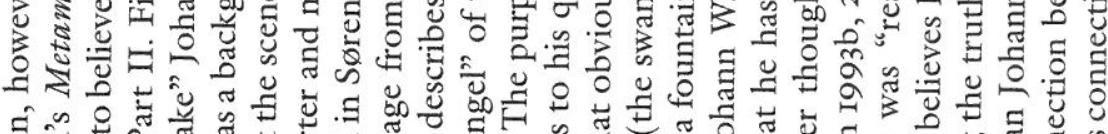

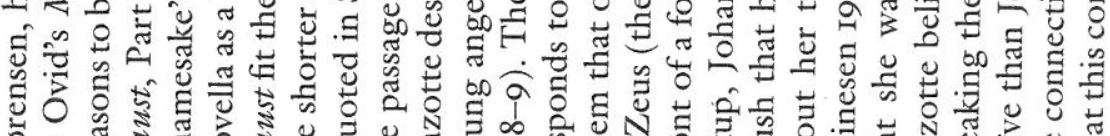

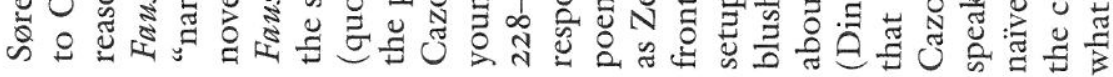




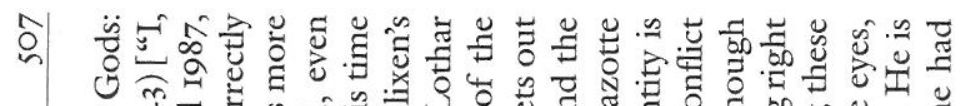

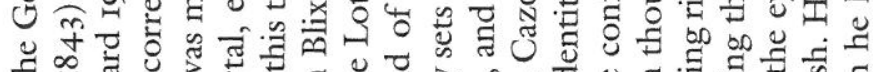

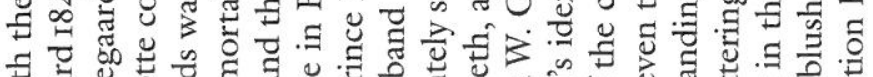

至

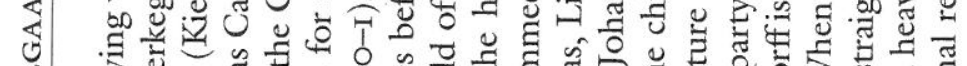

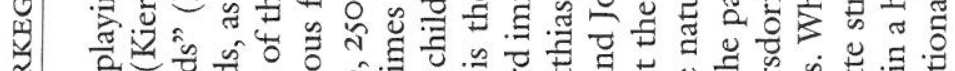

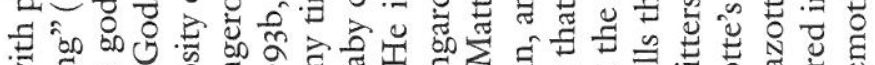
了:

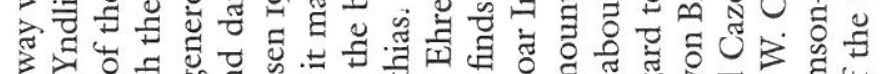

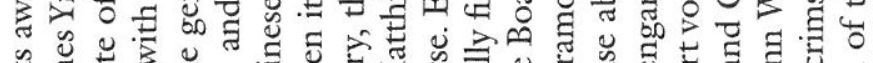

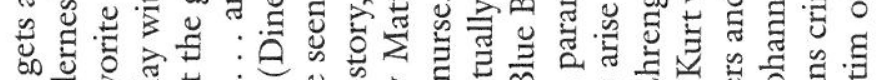

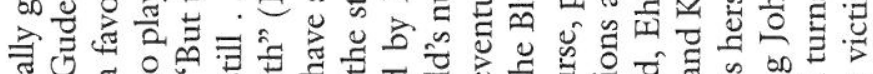

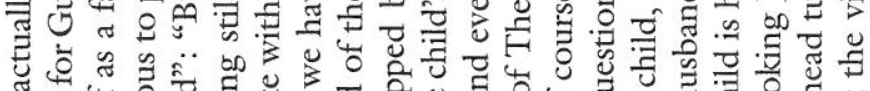

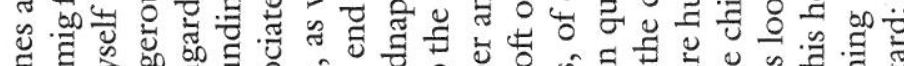

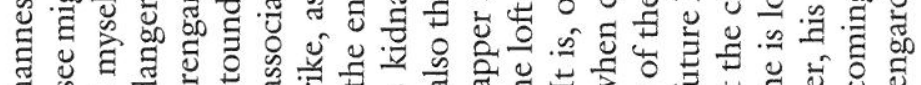

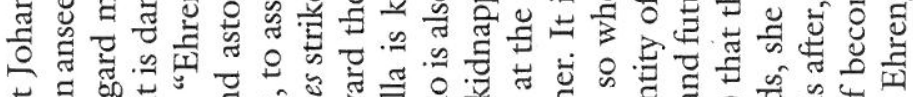

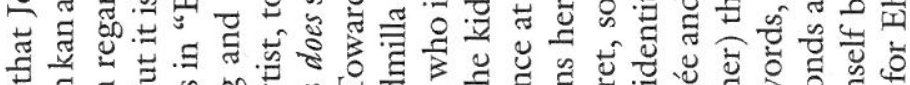

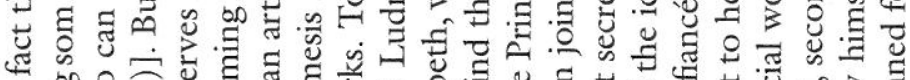

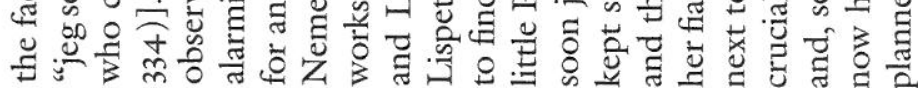

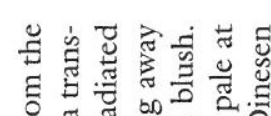

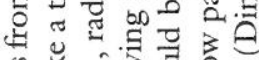

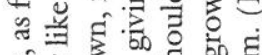

की

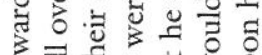

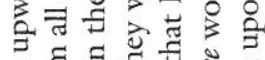

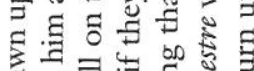

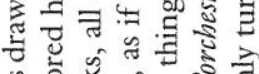

要융

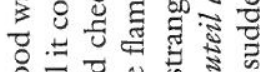

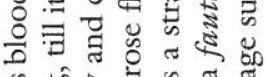

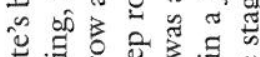

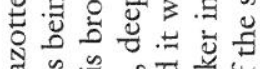

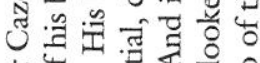

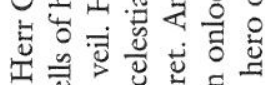

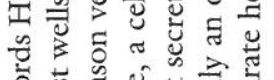

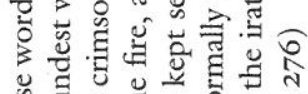

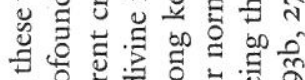

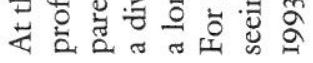

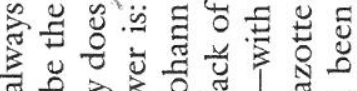

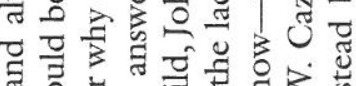
于

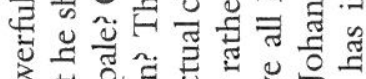

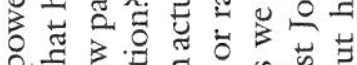
,

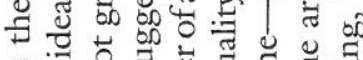
ڤั

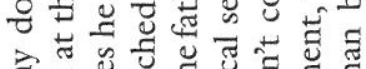

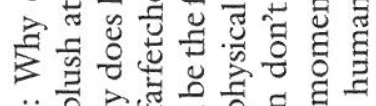

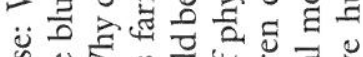

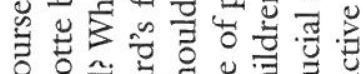

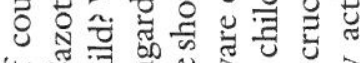
岁

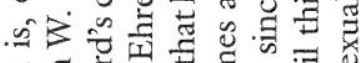
들

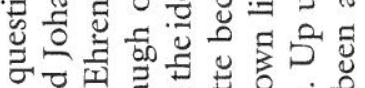
on

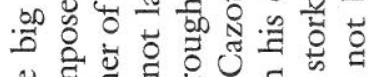

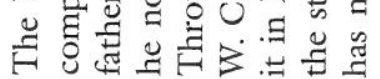

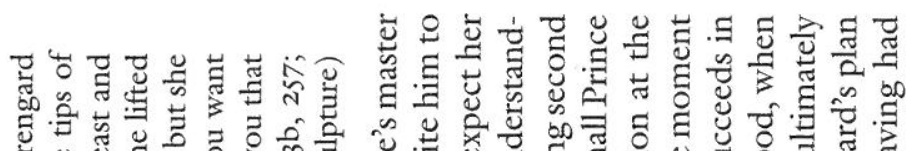

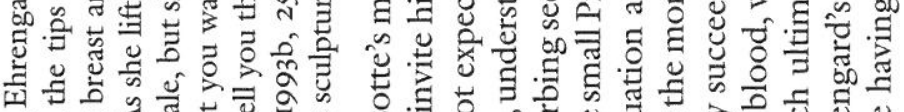

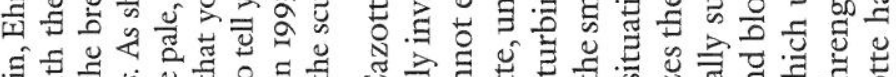

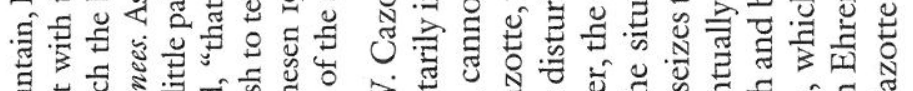

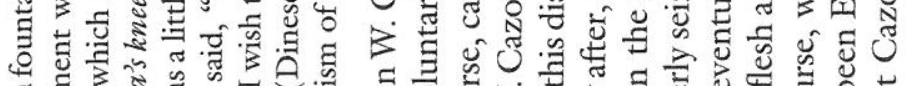

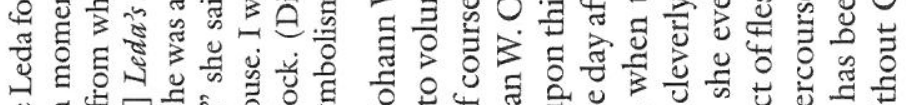

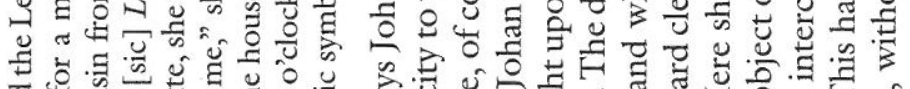

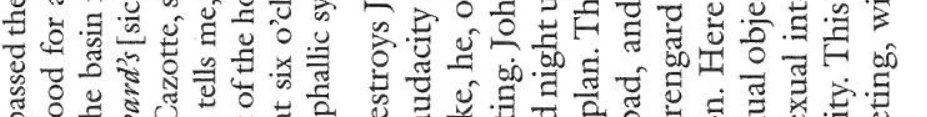

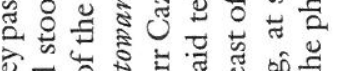

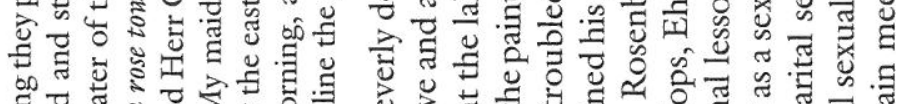

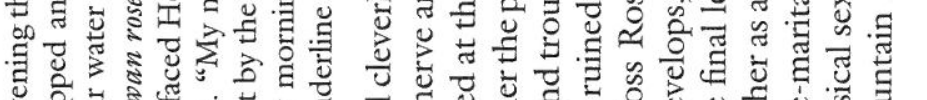

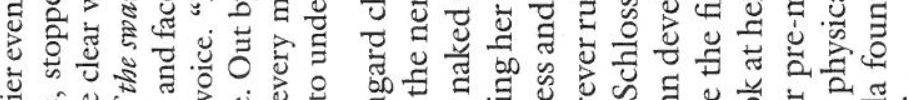

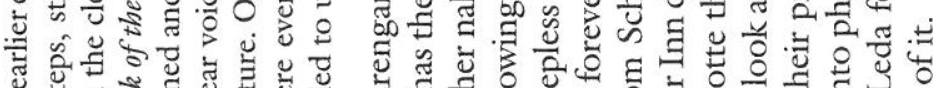

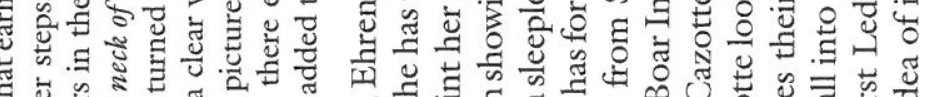

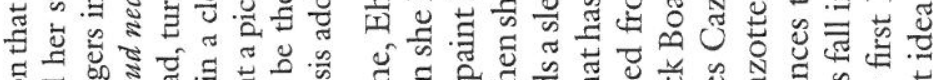

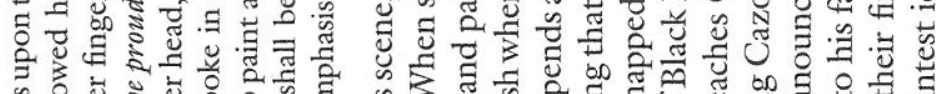

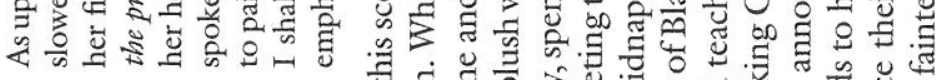

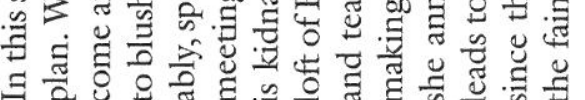

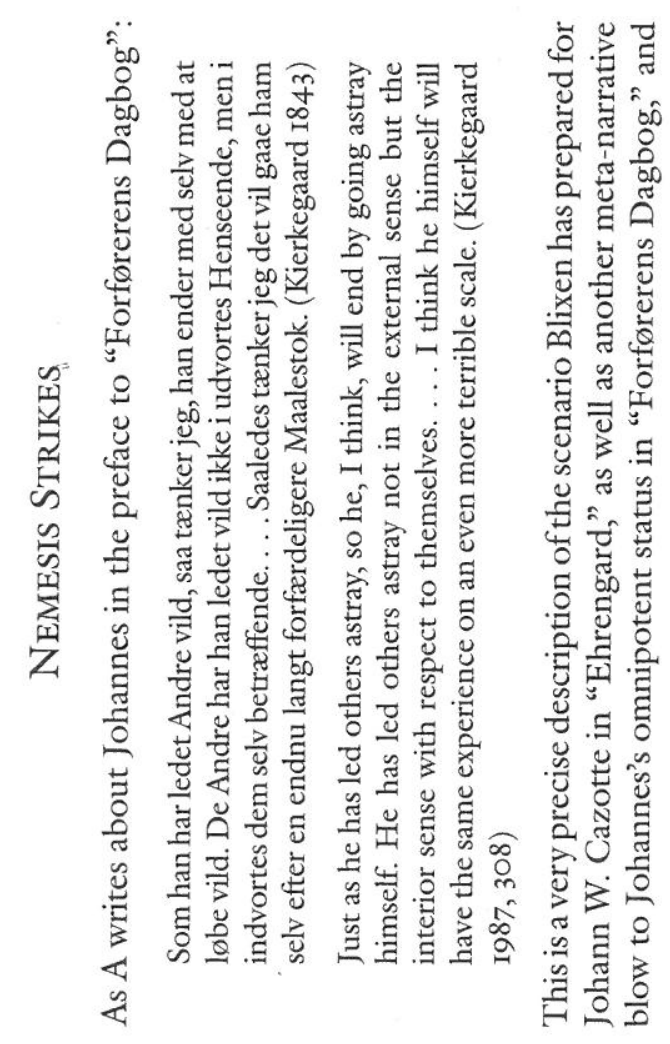



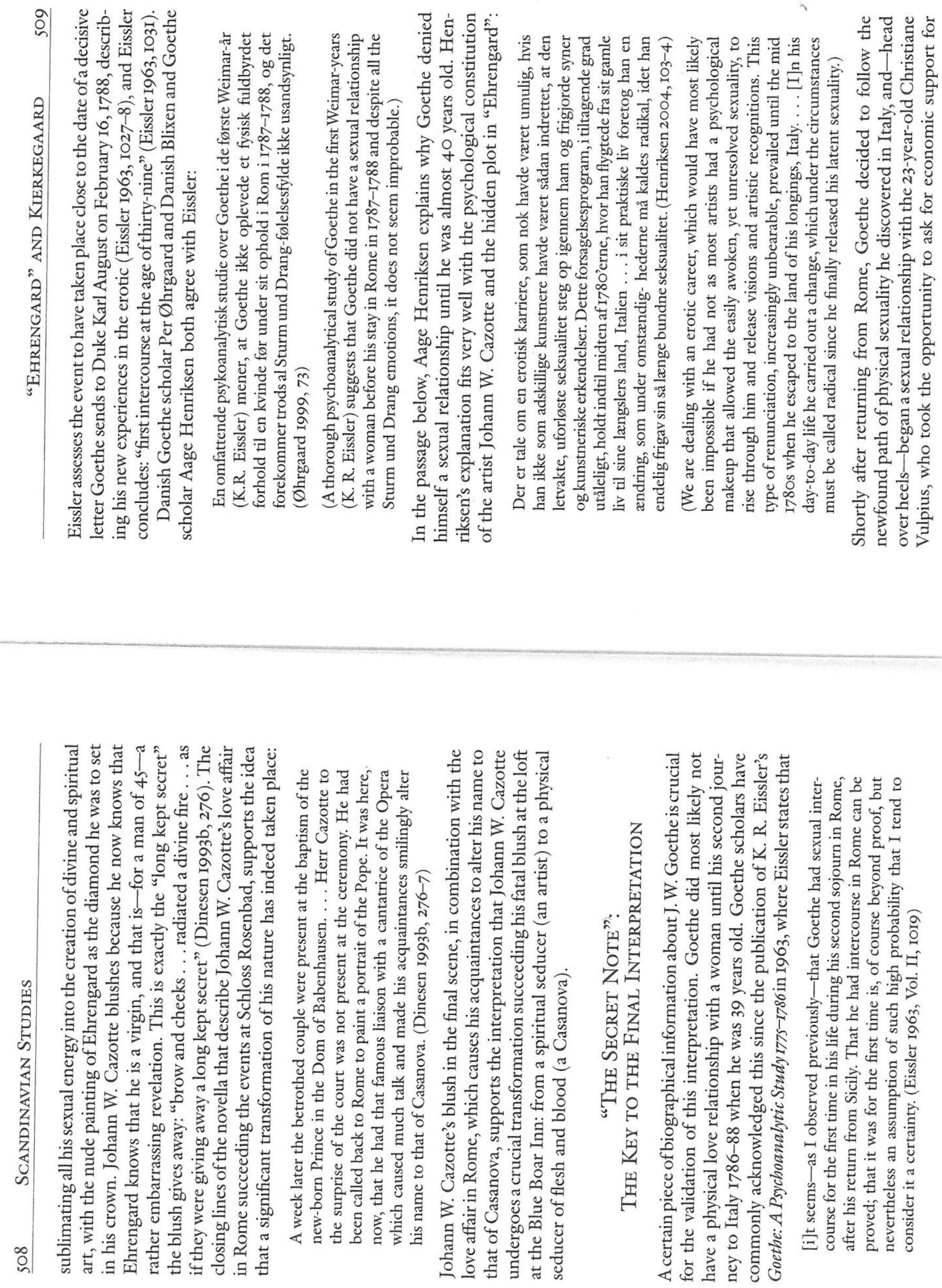


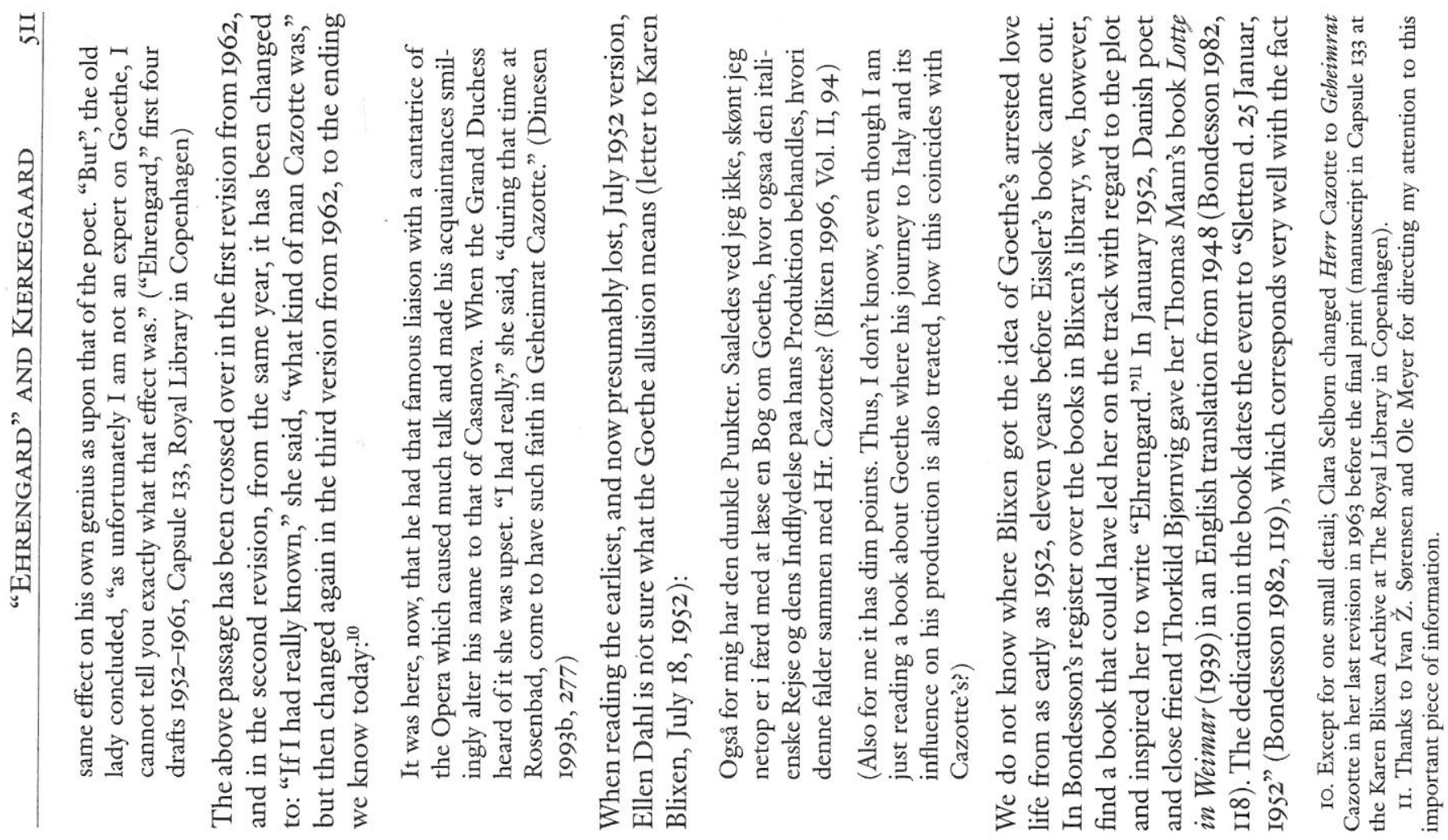

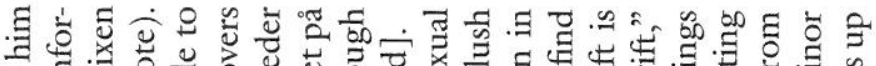

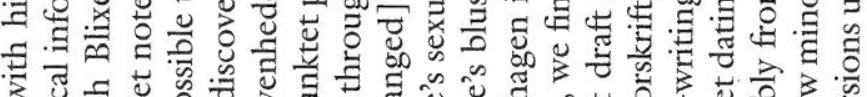

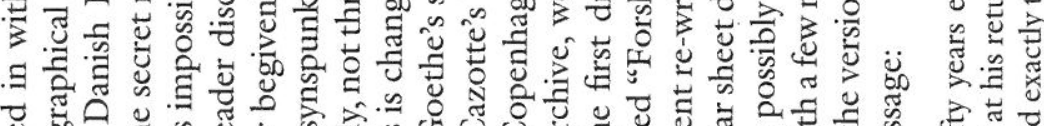

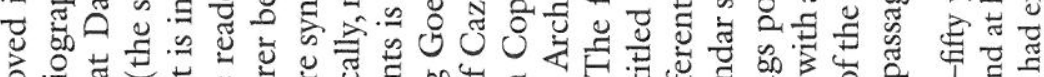

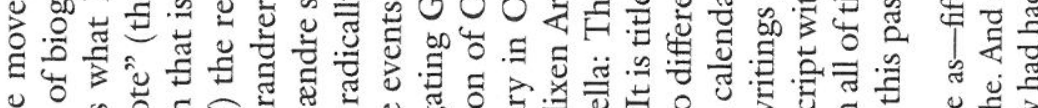

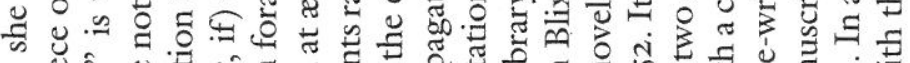

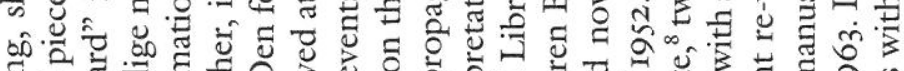

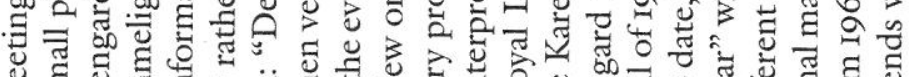

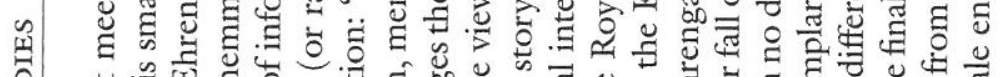

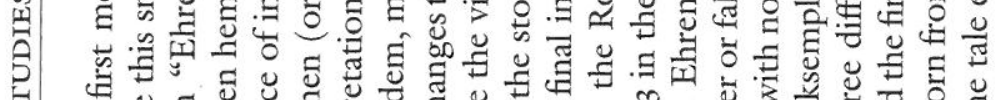
की

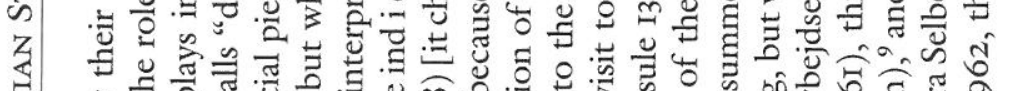

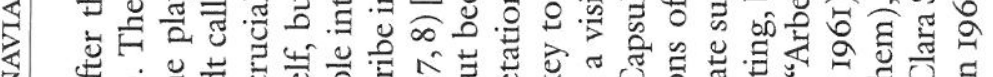

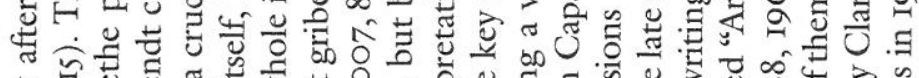

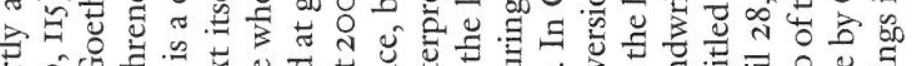
বी कै

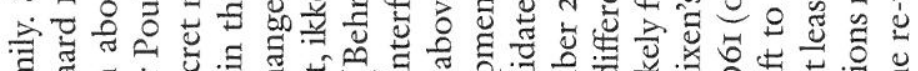

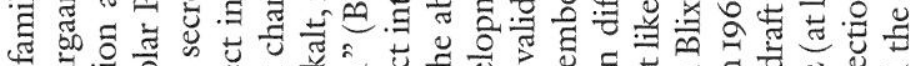

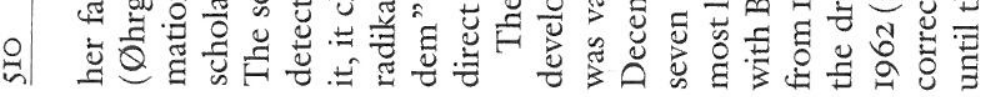

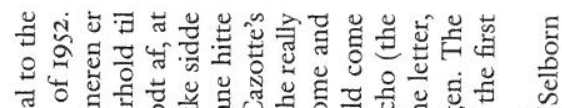

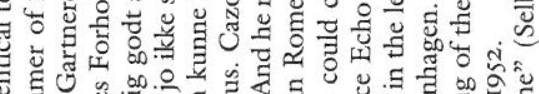

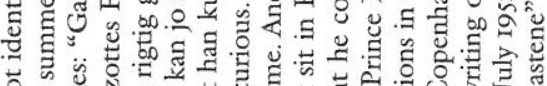

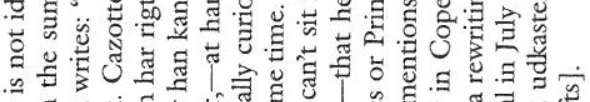

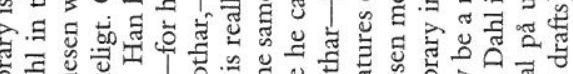

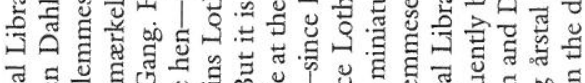

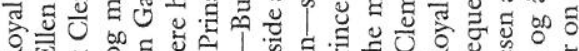

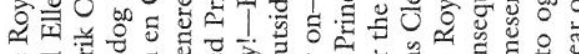

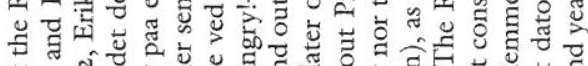

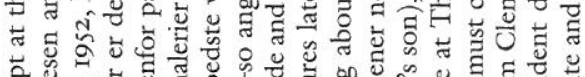

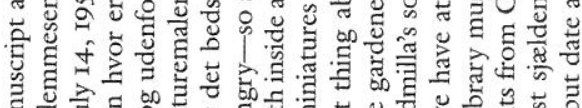

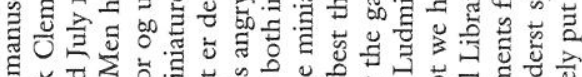

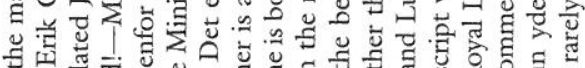

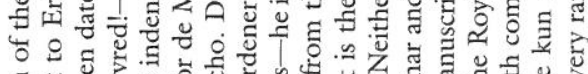

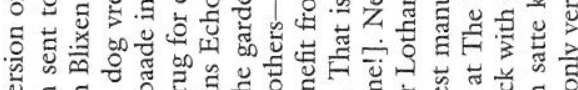

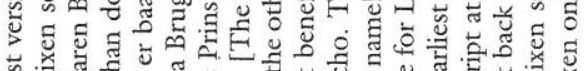

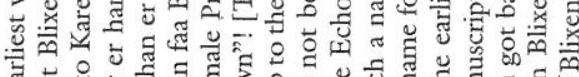

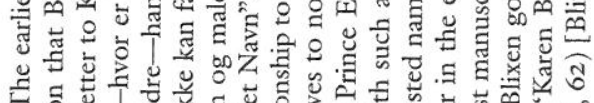

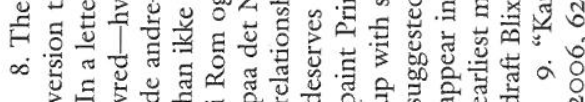




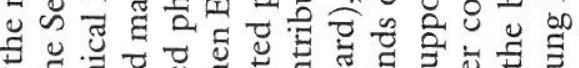

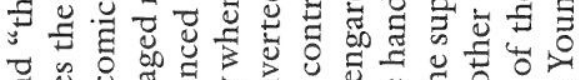

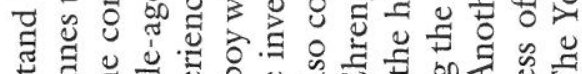

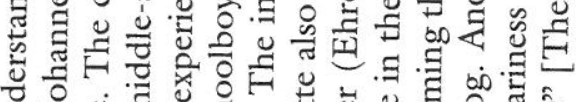

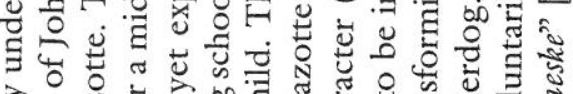

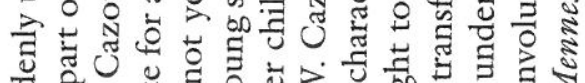

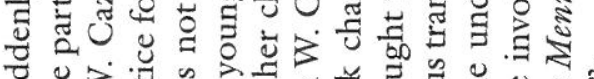

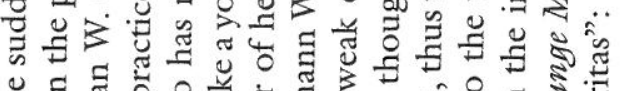

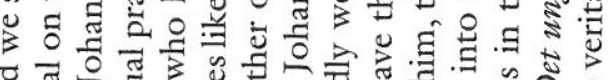

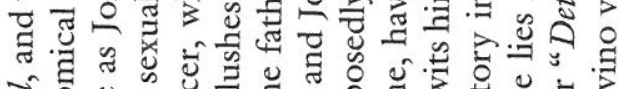
है

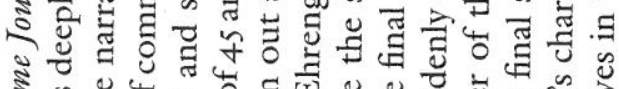

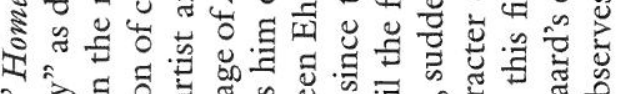

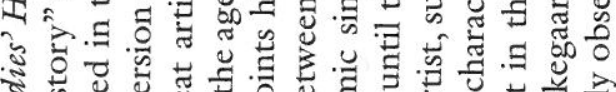

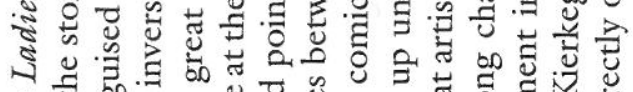

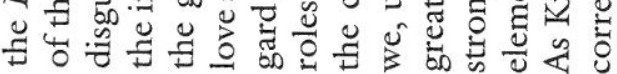

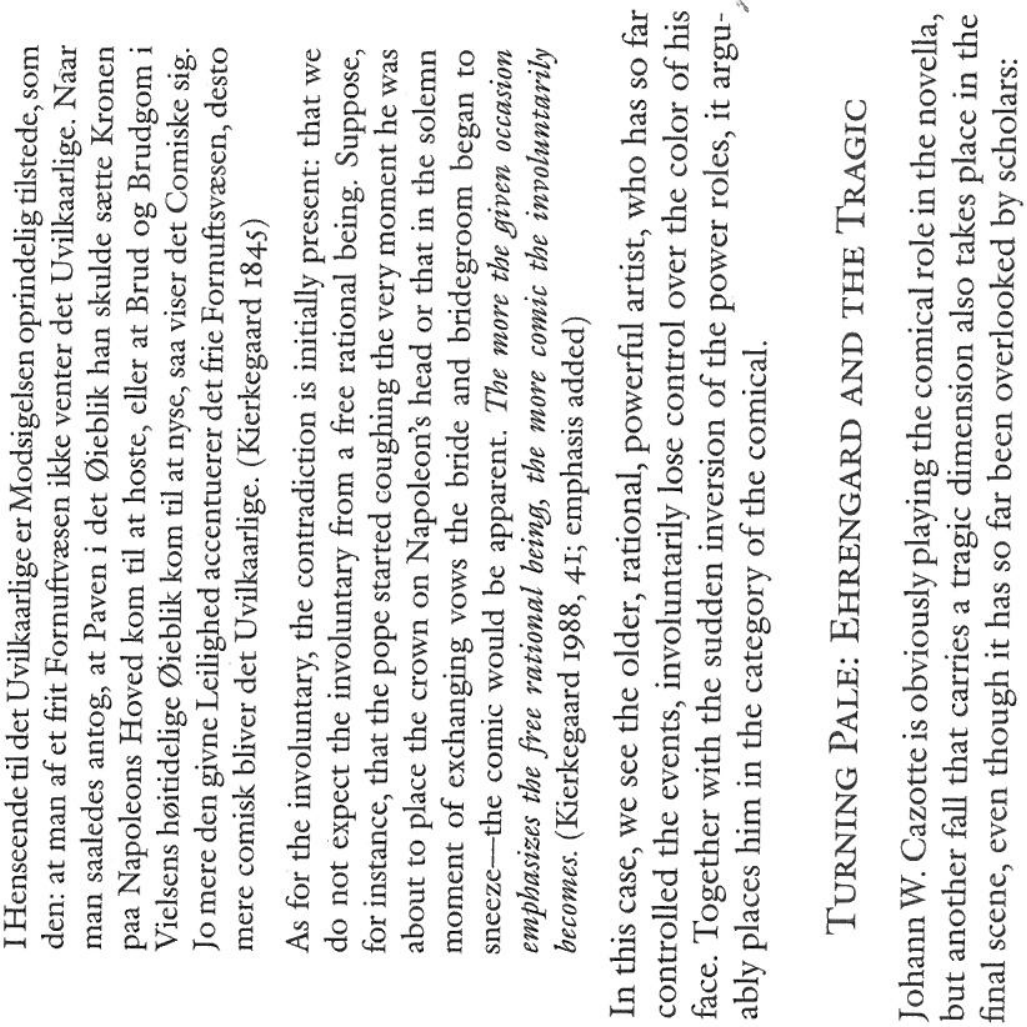

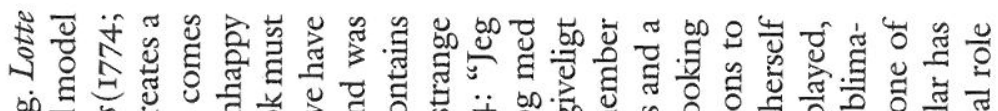

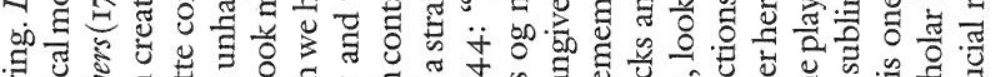

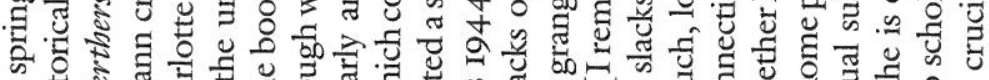

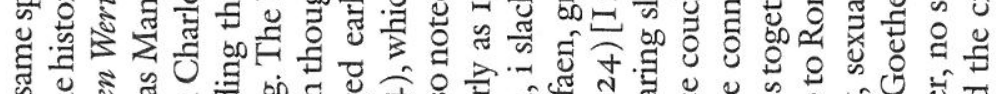

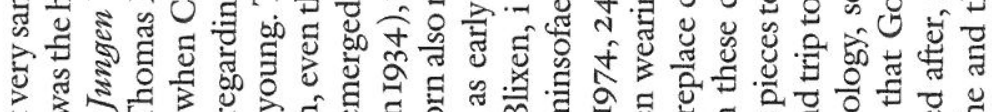

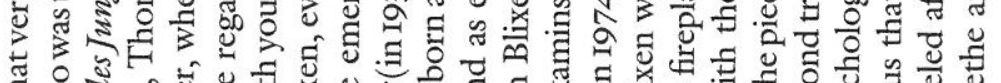

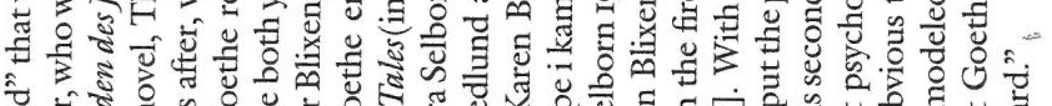

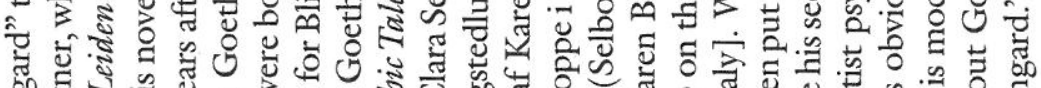

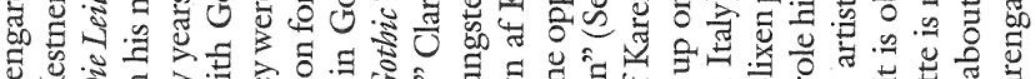

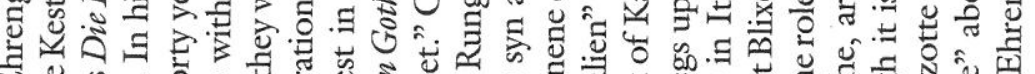

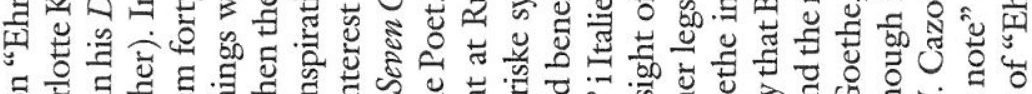

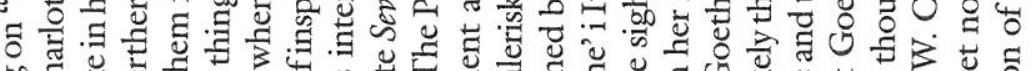
of

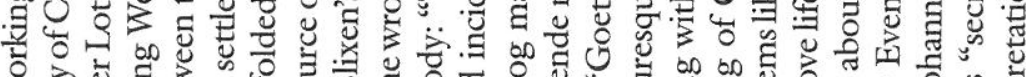

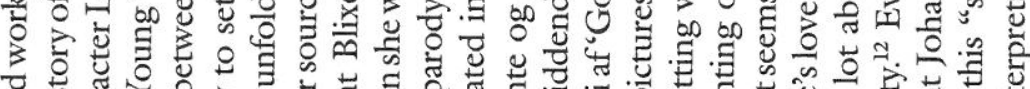
论

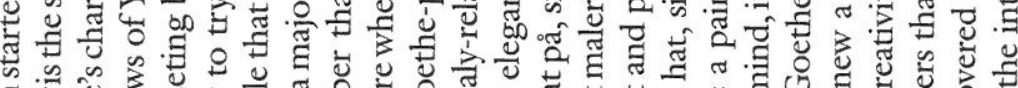

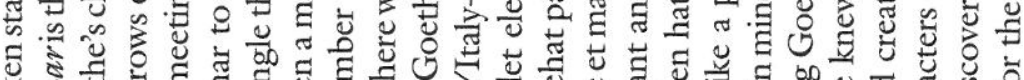
.

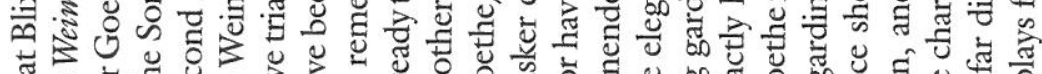

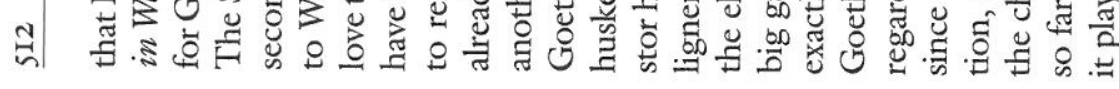

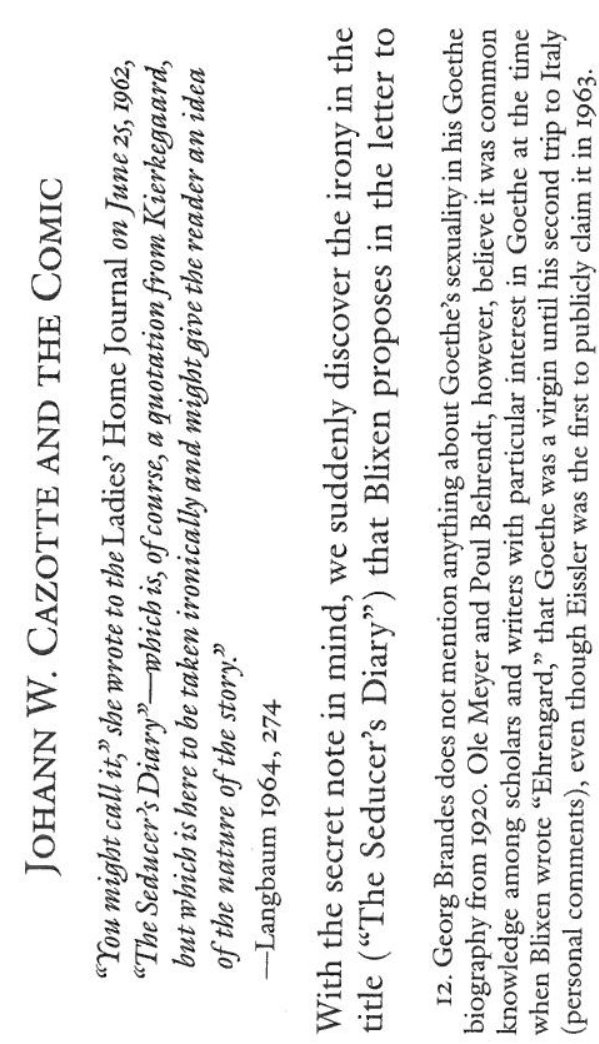



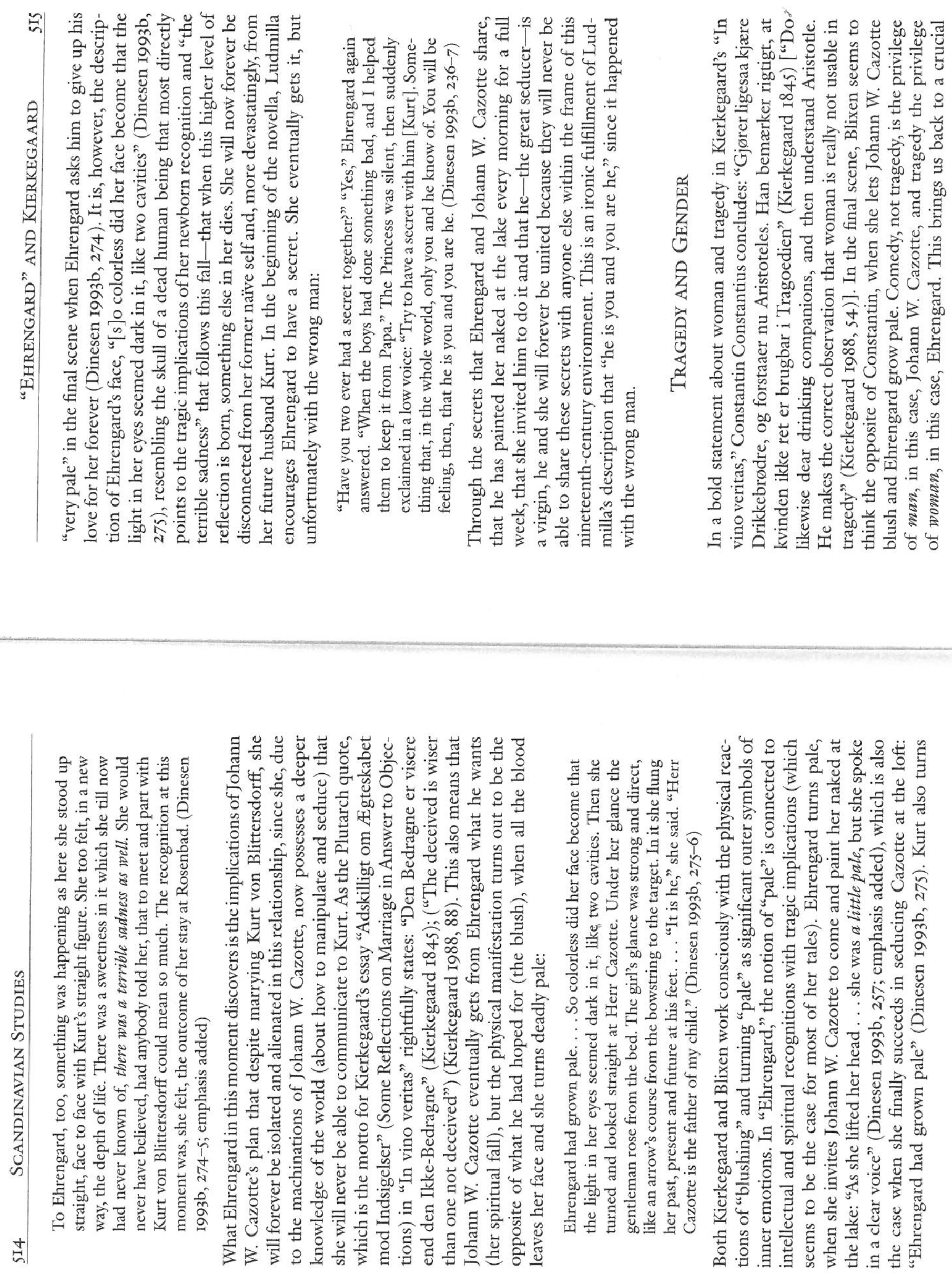

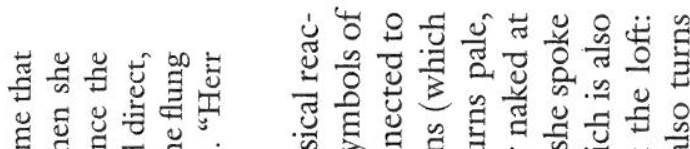

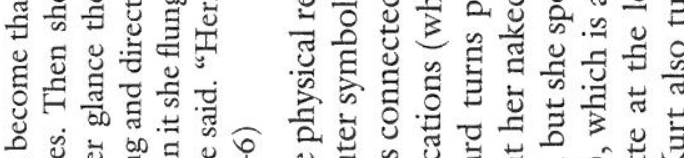

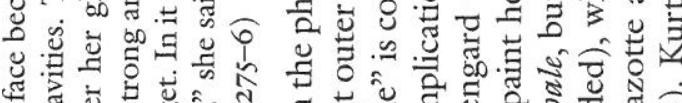

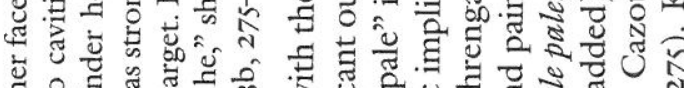

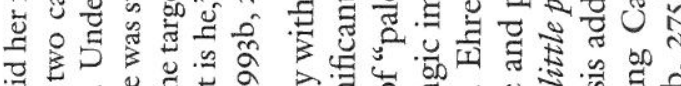
孝

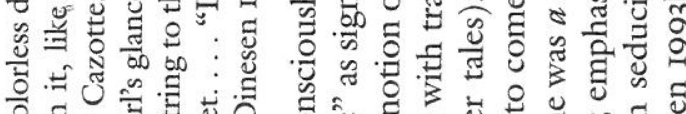

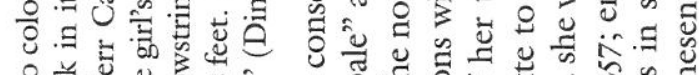

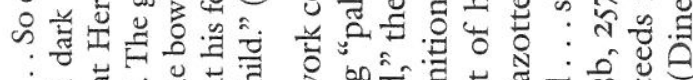

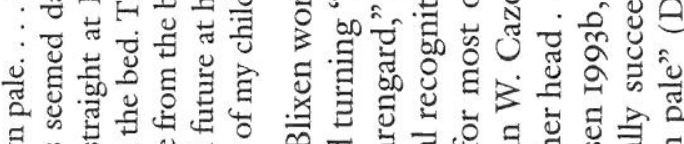
है क

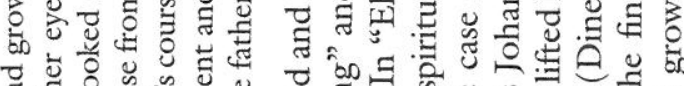
马्ष

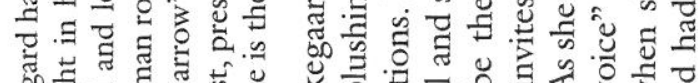

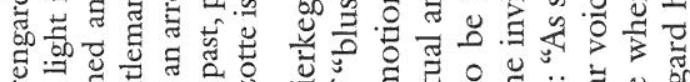

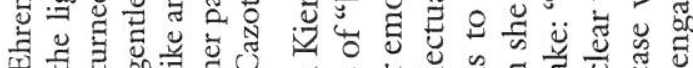

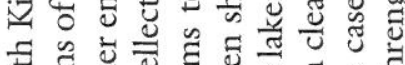

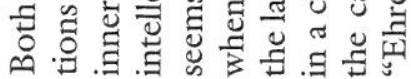




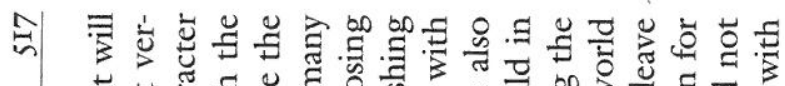

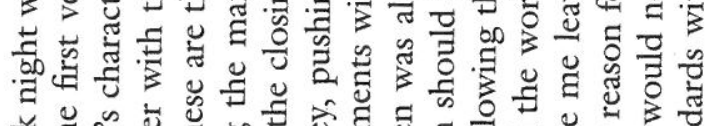

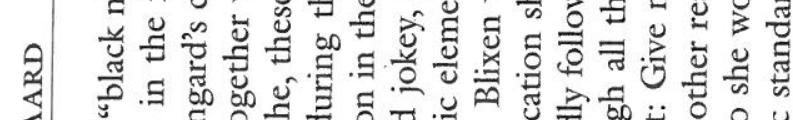

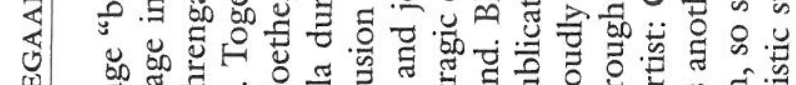

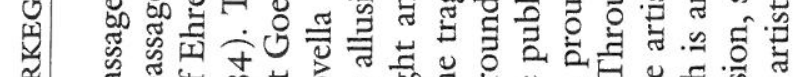

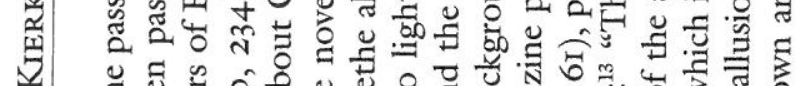

1)

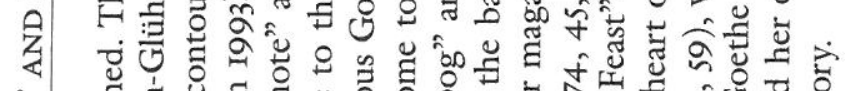

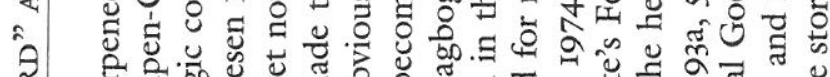

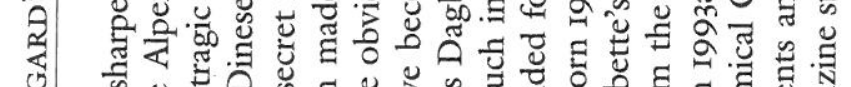

Z क

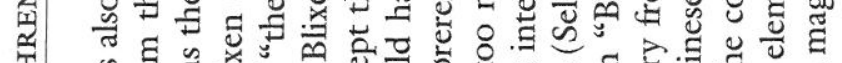

岳

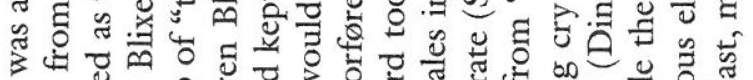

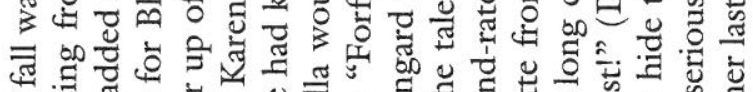

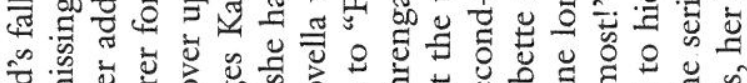

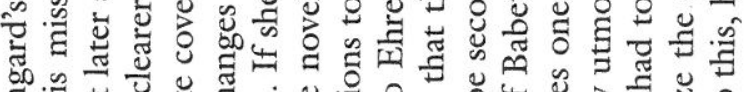
:

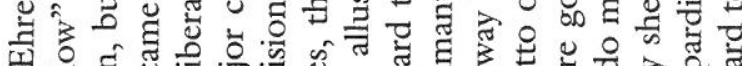

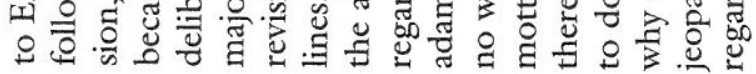

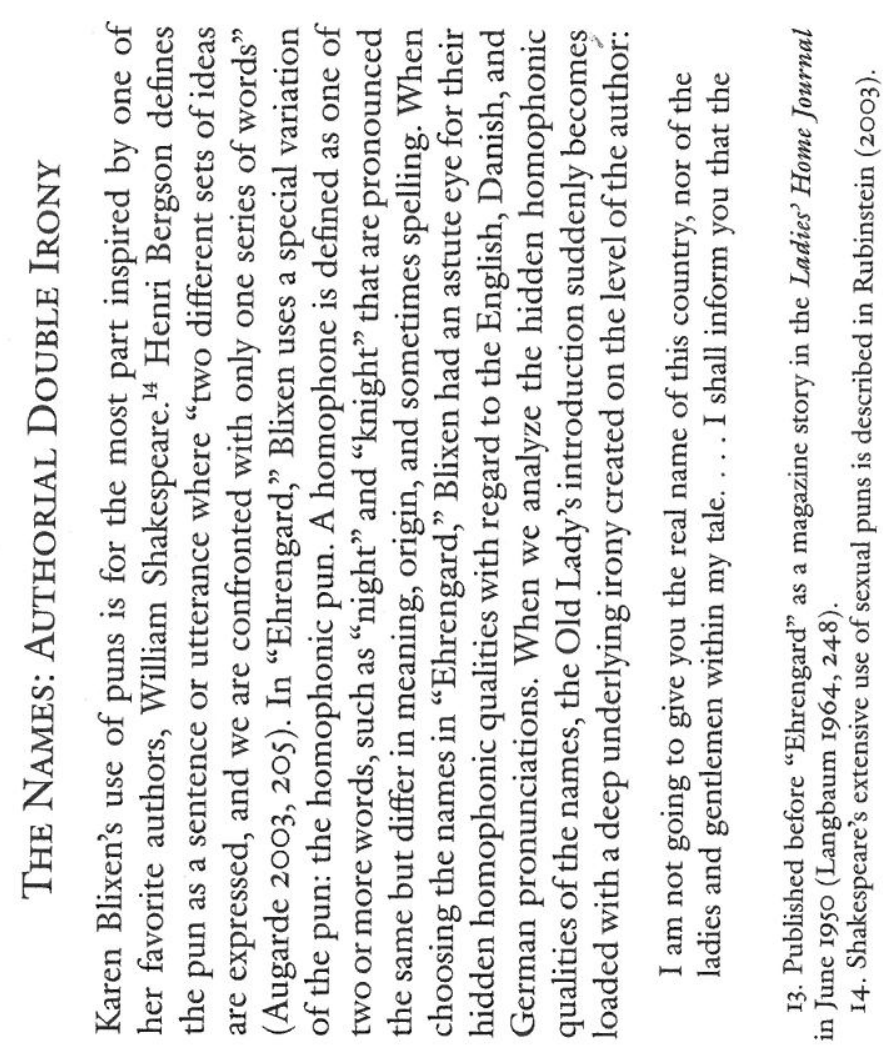

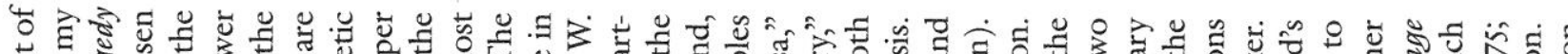

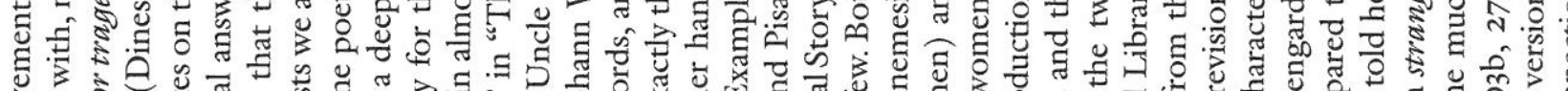

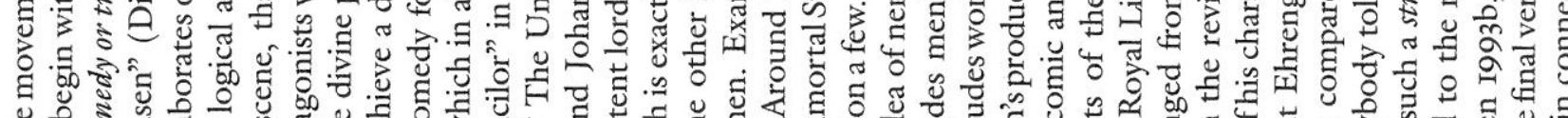

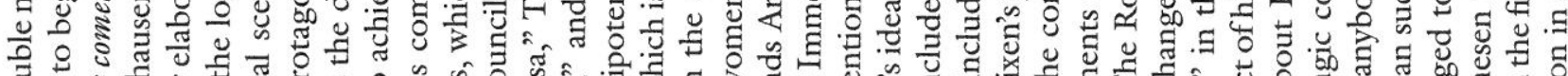

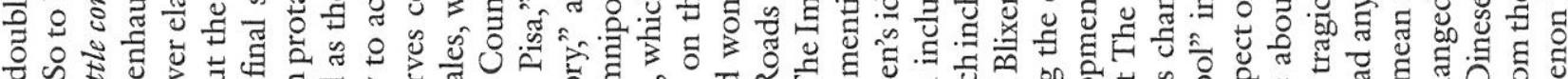
च

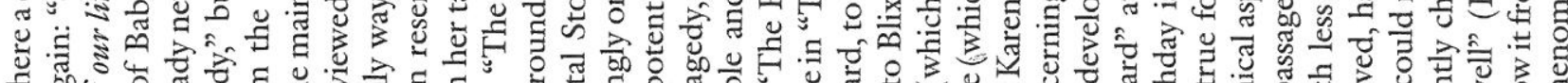

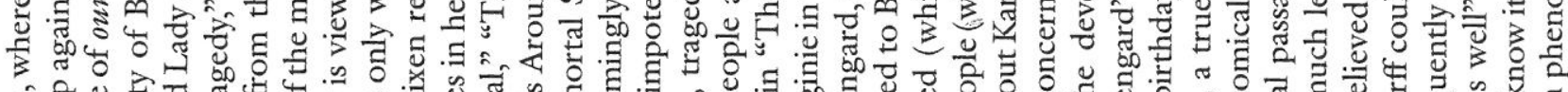

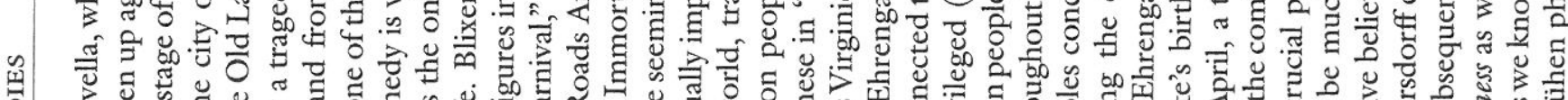

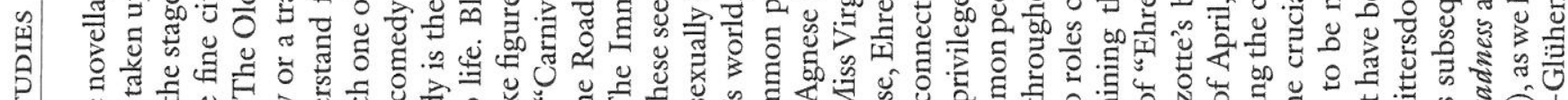
S

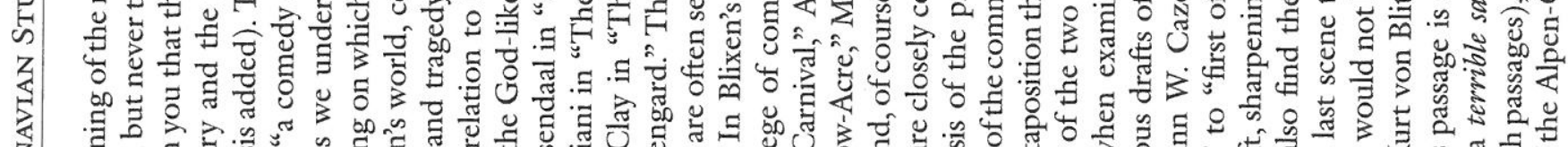
z

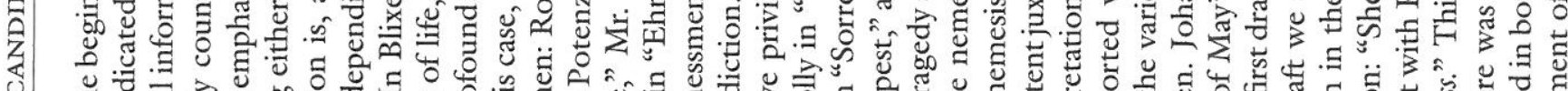

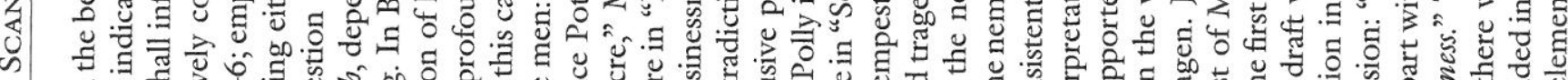

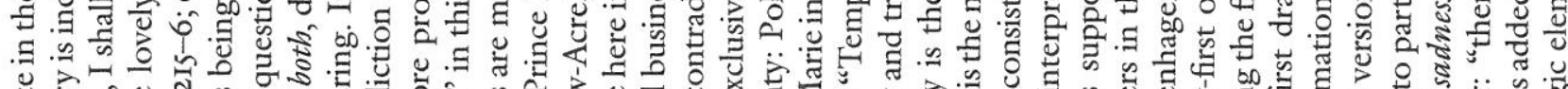

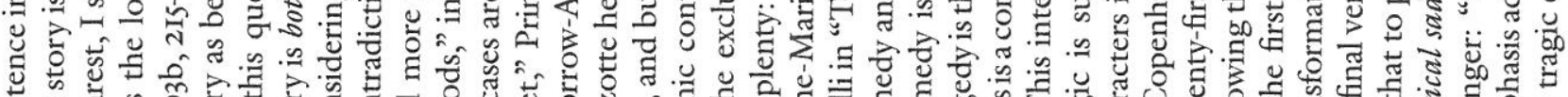
。 

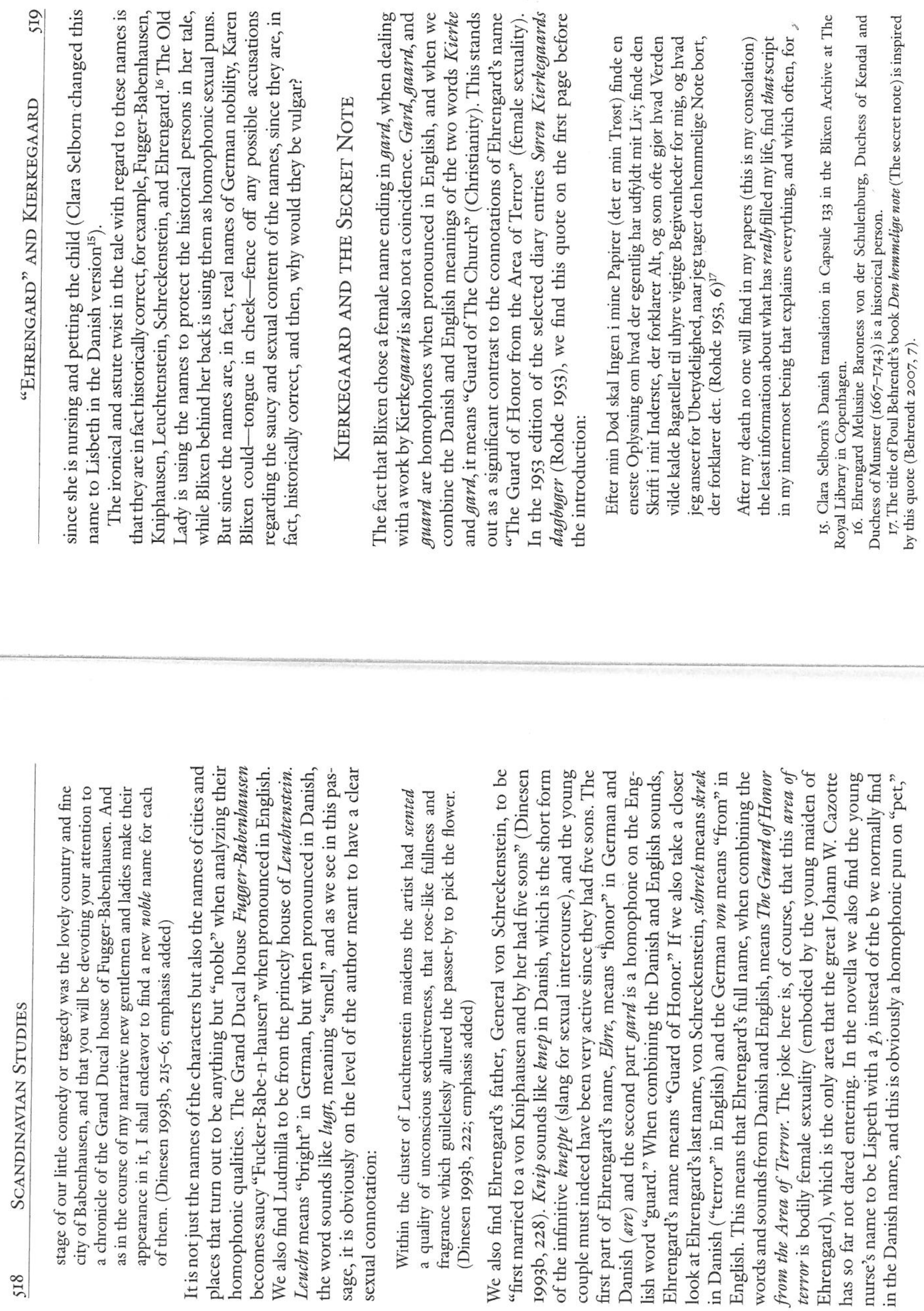


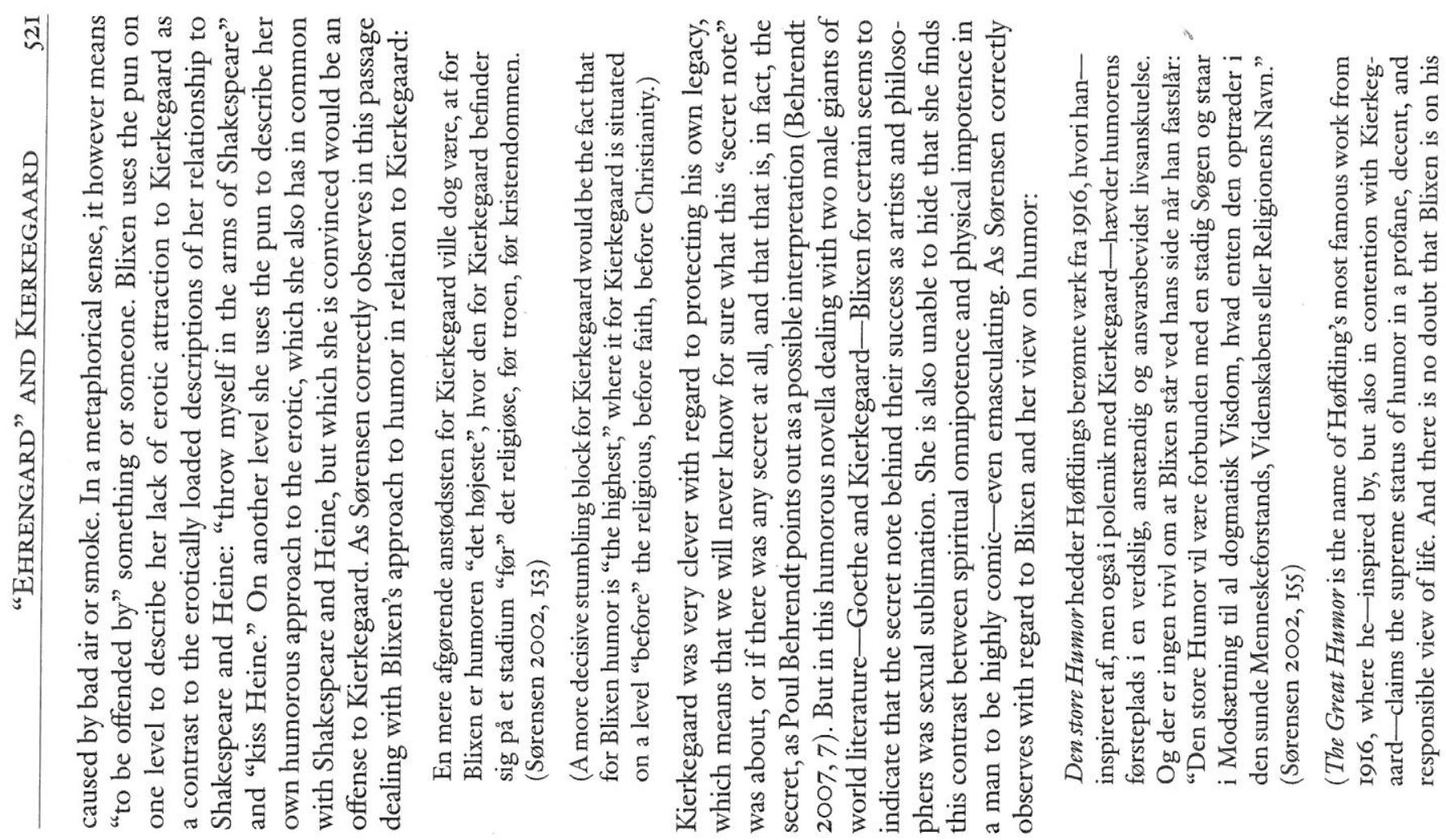

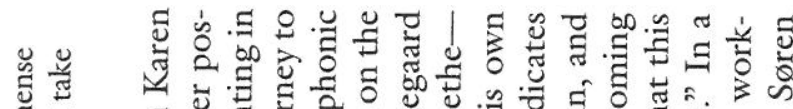

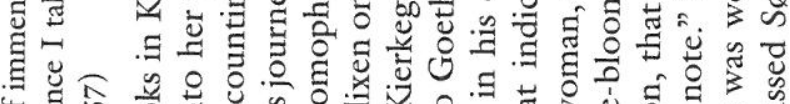

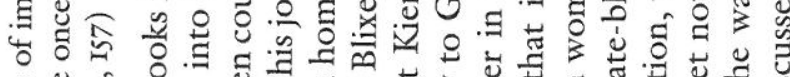

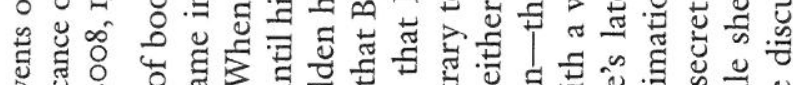

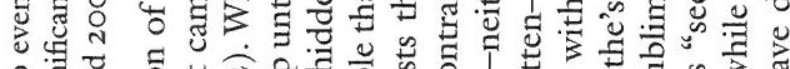

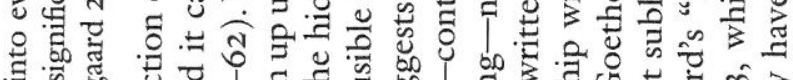

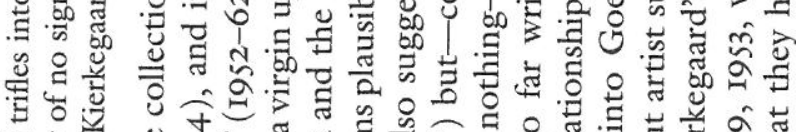

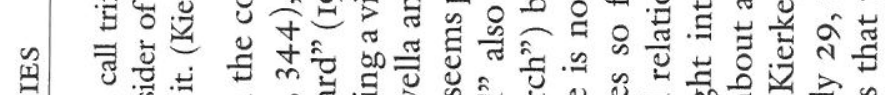

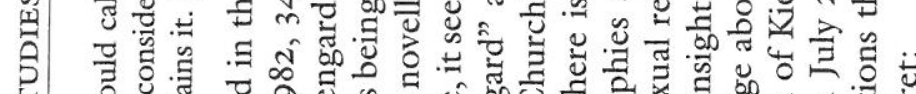

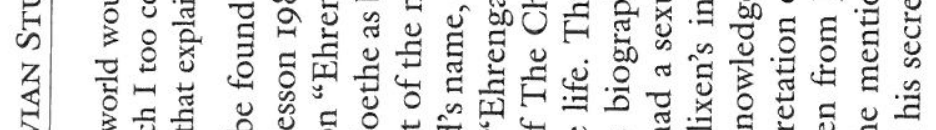
安

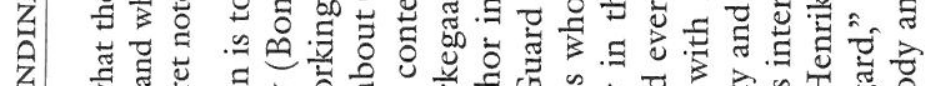

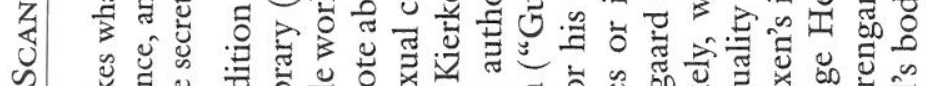

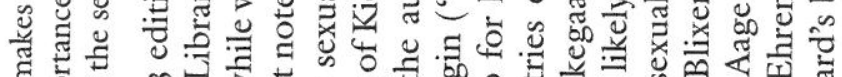
范

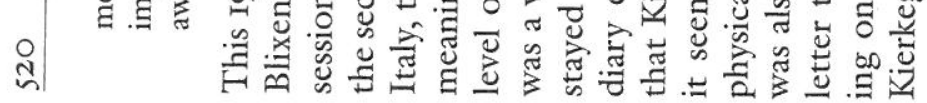

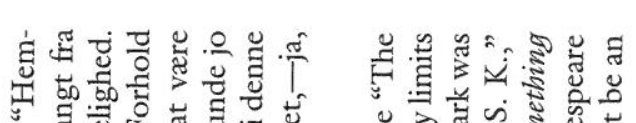

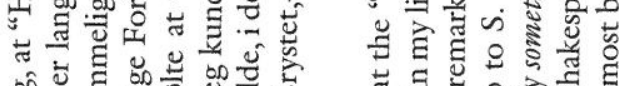

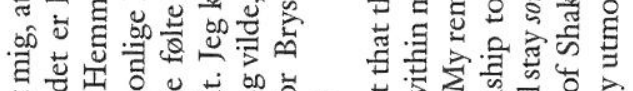

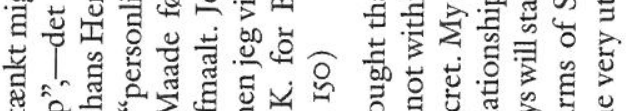

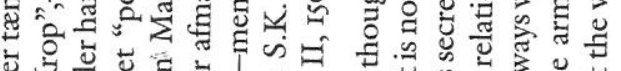

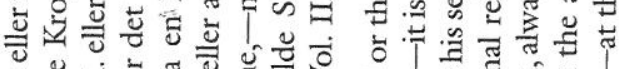

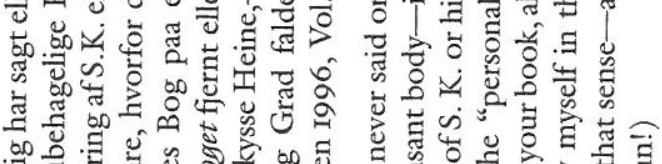

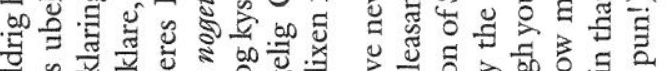

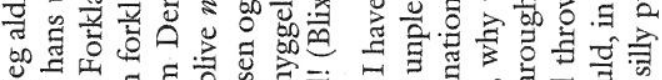

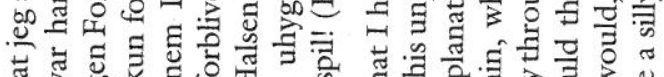

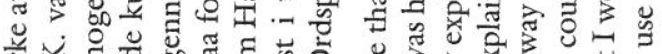

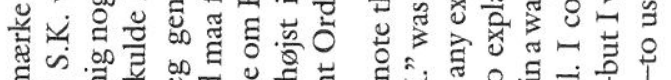

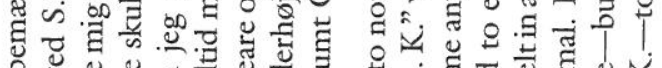
药

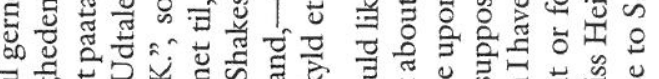

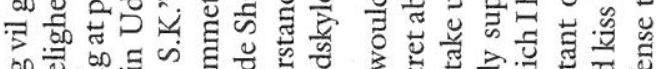

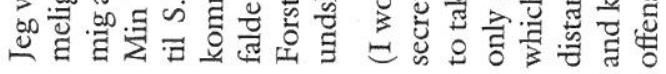



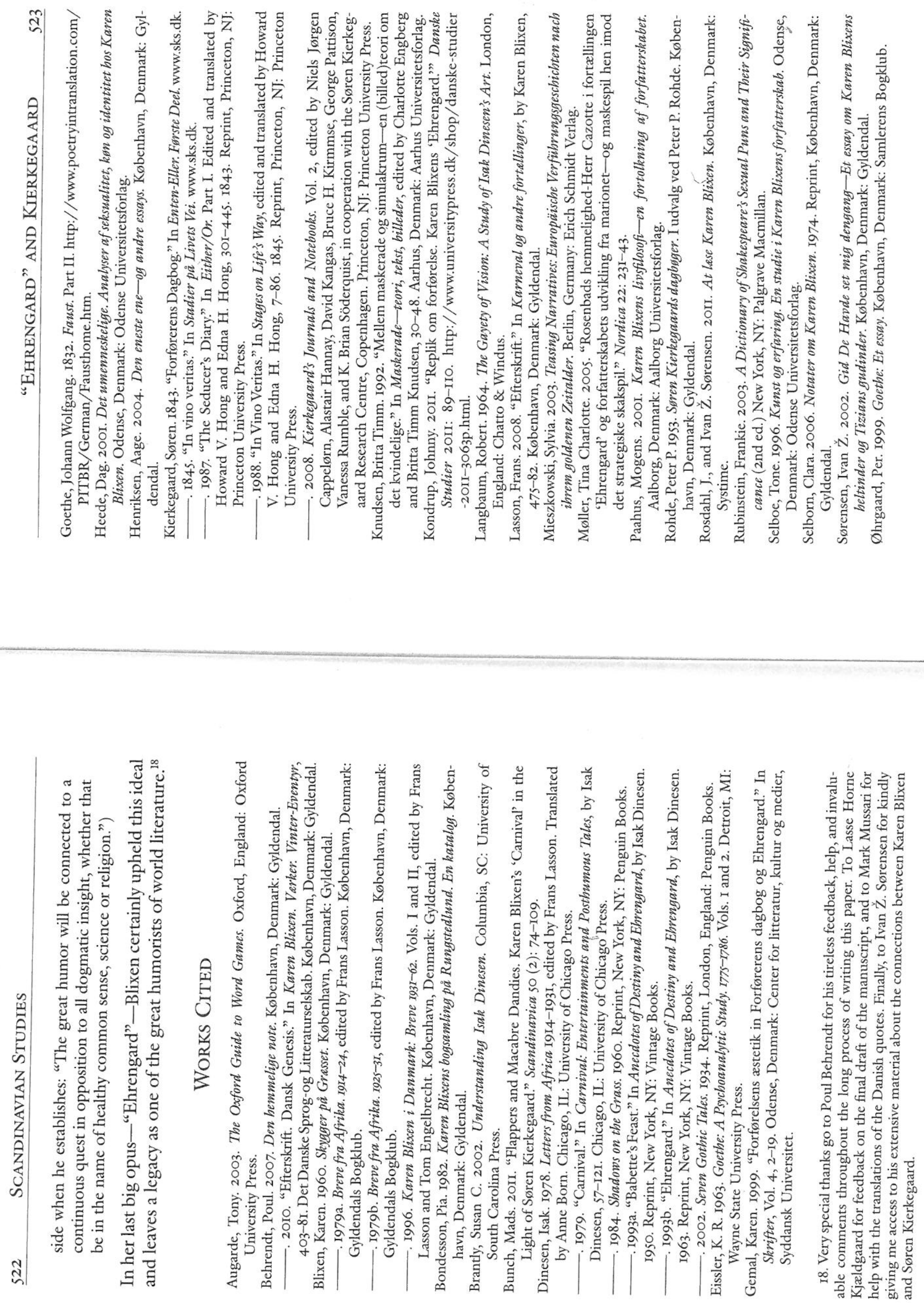